\title{
Älvaro Vieira Pinto e a dialética da informação
}

\author{
Álvaro Vieira Pinto and the \\ information dialectics
}

Marcos Dantas*

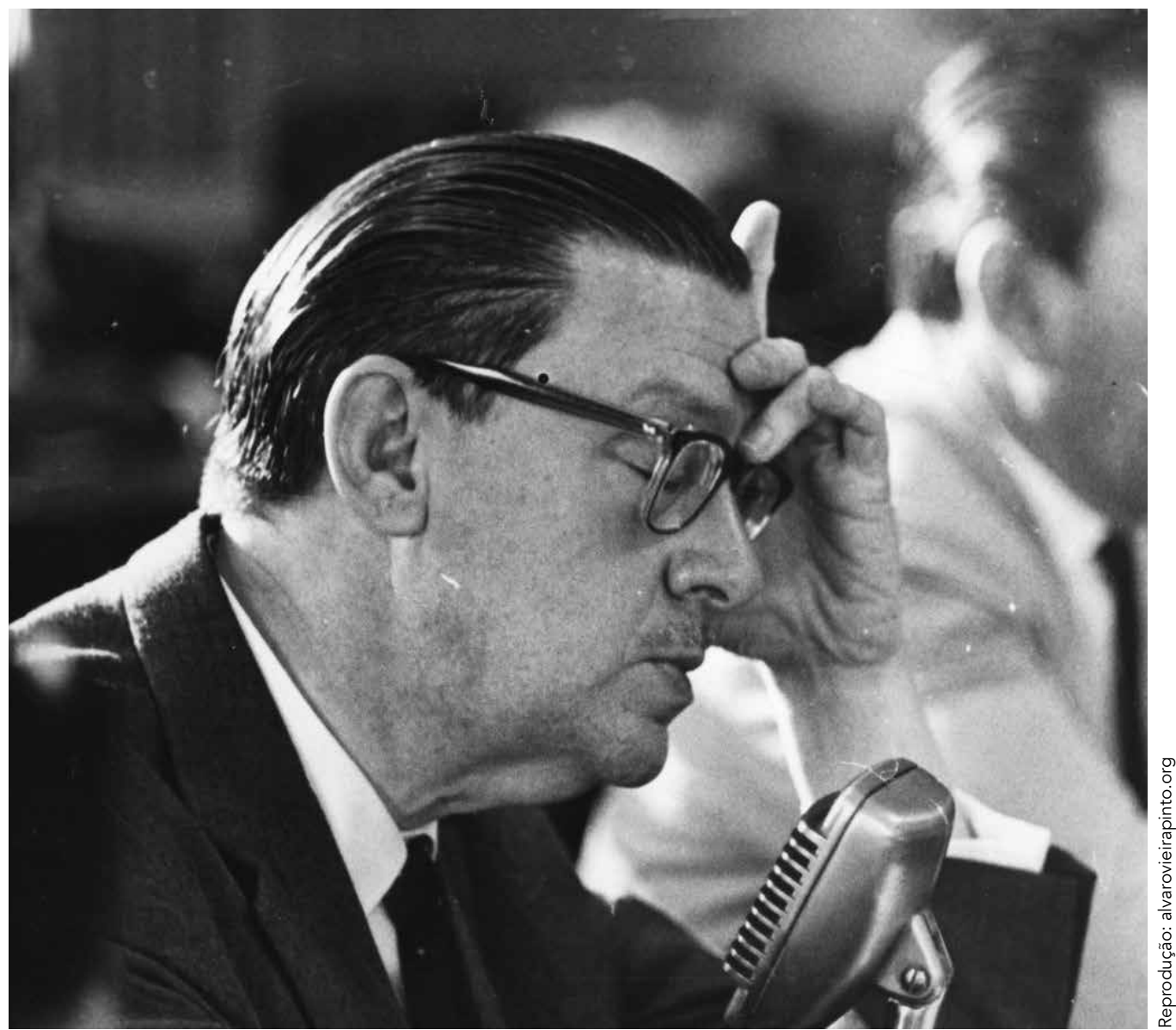

Álvaro Borges Vieira Pinto (1909-1987) destacou-se por sua posição materialista e dialética a respeito da realidade nacional subdesenvolvida e por sua atividade político-intelectual em defesa do desenvolvimento autônomo do Brasil durante o século XX 


\section{RESUMO}

Este artigo se propõe a expor e examinar o conceito dialético-materialista de informação elaborado pelo filósofo brasileiro Álvaro Vieira Pinto em relação com teorias e autores que desenvolveram a teoria da informação e a cibernética nos anos 1950 a 1970, tempo em que Vieira Pinto desenvolveu seu pensamento. A fonte básica é o segundo volume do seu tratado postumamente publicado, $O$ conceito de tecnologia. $\mathrm{O}$ artigo tem por objetivo, primeiramente, chamar a atenção para a extrema originalidade, mesmo no campo marxista, da abordagem dialética de Vieira Pinto sobre informação. Em segundo lugar, nas conclusões, chama a atenção para a importância de suas ideias serem incorporadas à atual agenda teórica e política, considerando as características do capital-informação contemporâneo.

Palavras-chave: Vieira Pinto. Informação. Cibernética. Trabalho.

\section{ABSTRACT}

This article aims to expose and examine the dialectical-materialist concept of information elaborated by the Brazilian philosopher Álvaro Vieira Pinto in relation to theories and authors who developed the theory of information and cybernetics in the I950s and I970s, when Vieira Pinto developed his thought. The basic source is the second volume of his posthumously published treatise, The concept of technology. The article aims, firstly, to draw attention to the extreme originality, even in the Marxist field, of Vieira Pinto's dialectical approach to information. Secondly, in the conclusions, it draws attention to the importance of his ideas being incorporated into the current theoretical and political agenda, considering the characteristics of contemporary information capital.

Keywords: Vieira Pinto. Information. Cybernetics. Work. 


\section{INTRODUÇ̃̃̃O}

A informação é "uma forma de movimento da matéria”, afirma Álvaro Vieira Pinto (2005, p. 379). Definição surpreendente! Para Manuel Castells, um dos mais conhecidos teóricos da assim chamada "sociedade da informação", citando, por sua vez, o economista Marc Porat, "informação são dados que foram organizados e comunicados” (PORAT apud CASTELLS, I999, p. 45, nota 27). Em Vieira Pinto, informação é uma forma de movimento, assim como as águas de um rio também estão em movimento. Para Castells, Porat e tantos outros e outras, informação é como se fosse uma "coisa”, um "objeto" que foi organizado, isto é, que já está lá para ser usado ou comunicado. São claramente distintas as duas definições e conceitos. E são claramente distintas essas duas abordagens, com todas as suas consequências epistemológicas, teóricas e mesmo político-econômicas, porque Vieira Pinto constrói um conceito de informação a partir de uma rigorosa abordagem materialista-dialética dos fenômenos informacionais, enquanto Marc Porat e, com ele, Manuel Castells enunciam uma definição positivista com base no senso comum.

O pensamento de Álvaro Vieira Pinto (I909-1987) vem sendo estudado de forma consistente desde os anos I980 e I990 (GONZATTO; MERKLE, 20I6), porém é ainda pouco difundido mesmo entre nós brasileiros ${ }^{1}$. Talvez não seja equivocado afirmar que, por outro lado, o interesse pelas suas ideias cresceu após a publicação póstuma, pela editora Contraponto, do seu volumoso O conceito de tecnologia (VIEIRA PINTO, 2005). Mas boa parte da sua obra está esgotada, é difícil de ser encontrada. Graduado inicialmente em medicina, profissão que chegou a exercer, formou-se adiante em física, matemática e lógica, vindo a ser professor na antiga Faculdade de Filosofia da Universidade do Brasil. Intelectualmente foi primeiro influenciado por Heidegger, um filósofo alemão que debatia, de um ponto de vista fenomenológico, a relação entre sociedade e tecnologia nos anos I930-I940, tendo em conjunto com muitos outros pensadores apresentado uma visão negativa, pessimista, da relação entre o ser humano e suas tecnologias. Provavelmente dessa relação original Vieira Pinto tenha tido os seus primeiros contatos com o tema da tecnologia. Nos anos I950-I960, Vieira Pinto adere ao marxismo, passa a integrar o Instituto Superior de Estudos Brasileiros (Iseb) e torna-se um dos mais profícuos pensadores do desenvolvimentismo brasileiro, dialogando e convivendo com Paulo Freire, Celso Furtado, Nelson Werneck Sodré, Roland Corbisier e tantos outros envolvidos naquele projeto de pensar o Brasil como uma potência industrial, além de socialmente justa, nos anos que se seguiriam. Projeto frustrado pelo golpe de 1964 .

O golpe obrigou Vieira Pinto a se exilar. Ele passa um período na Iugoslávia, depois vai para o Chile, onde provavelmente trava contato com as ideias cibernéticas

Para mais detal hes da vida e obra de Alvaro Vieira Pinto, ver o verbete "Álvaro Vieira Pinto" na Wikipédia: $<$ https://pt.wikipedia.org/wiki/Álvaro_Vieira_Pinto>. Ver também a Rede de Estudos Álvaro Vieira Pinto: $<w w w . a l v a r o v i e i r a p i n t o . o r g>$. Gonzatto e Merkle (2016) e Freitas (2005) nos fornecem também amplo apanhado de sua vida, obra e pensamento, incluindo referências a outros autores e autoras que têm estudado a sua obra. 
que então mobilizavam um grupo de teóricos e tecnólogos chilenos na organização e implantação de uma rede de comunicação similar à que um dia seria chamada de internet. Volta ao Brasil em I968 e passa a viver aqui de traduções, quase sempre assinadas por algum pseudônimo. Ele não está clandestino, mas também não pode se expor. E é nesse período que se dedica aos estudos e à redação daquele poderoso tratado que termina de escrever em I974, mas só veio à luz em 2005. Entre os livros que traduziu, sob pseudônimo, conforme Gonzatto e Merkle, está Teoria geral dos sistemas, obra seminal de Ludwig von Bertalanffy, e também títulos de Noam Chomsky, Jean Piaget, Hans Rapp, West Churchman, John Postgate, autores que, escrevendo sobre cibernética, linguagem, biologia ou teoria de sistemas, certamente contribuíram para aprofundá-lo nesses temas e elaborar as ideias que desenvolveria nessa época.

Por duas vezes, no texto introdutório acima, está escrito "provavelmente". Há lacunas na formação do pensamento de Vieira Pinto que mesmo estudiosos mais avançados ou mais conhecedores do que eu, com os quais dialoguei pessoalmente, têm dificuldade de preencher ${ }^{2}$. Gonzatto e Merkle (20I6, p. 287) admitem que sua obra "ainda permanece de difícil acesso e tímida circulação". A questão, entre outras que podemos suscitar, pensando no que era a sociedade brasileira na primeira metade da década 1970 e pensando também no que era a agenda da esquerda brasileira e sul-americana no final dos anos 1960 e nos primeiros anos 1970, é esclarecer as influências que levaram Vieira Pinto a se entregar tão profundamente a uma investigação que parecia tão distante da nossa realidade e dos temas que nos mobilizavam àquela época: o conceito dialético de informação. Porém, antecipemos: não é questão a que se possa ou se pretenda responder neste artigo. Aqui, apenas, pretende-se apresentar o conceito de Vieira Pinto aos leitores, em diálogo com outros pensadores e cientistas; e sugerir, ao final, alguns desdobramentos teóricos e políticos. A rigor, até hoje, no campo marxista e nos demais segmentos da esquerda, esse é um tema quase nunca abordado, ou, se abordado, não o será de forma muito distinta daquela de Manuel Castells.

Vieira Pinto, no Chile, já tinha escrito, com base em palestras, o também volumoso Ciência e existência (VIEIRA PINTO, I979). Nessa obra ele trata de um tema que de fato estava na agenda, na medida em que, como dito acima, Heidegger e tantos outros pensadores, a partir da Segunda Guerra Mundial, a exemplo de Theodor Adorno, Jacques Ellul (com quem ele muito dialoga criticamente), Gilbert Simondon, Herbert Marcuse, o primeiro Habermas, vinham discutindo e tentando entender essa relação entre a ciência, a tecnologia e a sociedade. Mas Vieira Pinto - considerando-se, repetindo, o nosso ambiente intelectual à época - vai muito além deles em conceito de tecnologia: mediante a sua abordagem dialética, ele defende a relação constitutiva entre o ser humano e a tecnologia (esta não pode ser vista como algo "externo" ao ser humano, que o determinaria, para o "bem" ou para o "mal"), e dedica todo o 
segundo volume, de quase 800 páginas, a discutir a cibernética e a teoria da informação, um campo científico e uma teoria que mal tinham 30 anos de história quando escreveu esse seu magnum opus. Ele vai nos legar um conceito dialético-materialista de informação extremamente original mesmo nos círculos dialético-materialistas da época, cujo centro de irradiação ainda era a União Soviética, seu Partido Comunista e sua poderosa Academia de Ciências.

Tanto a cibernética quanto a teoria da informação tinham "nascido" em I948, com a publicação de Cybernetics, por Wiener (1985), e "A mathematical theory of communication", por Shannon (I948). Na URSS, durante o governo de Stalin, seriam acusadas de "ciências burguesas" e seu estudo e desenvolvimento, praticamente impedido. A partir da segunda metade da década de I950, um grupo de eminentes matemáticos, alguns deles também integrados ao sistema soviético de defesa militar, conseguiu reverter tal preconceito, mas, para tanto, além de demonstrar a importância dessa nova ciência para o próprio desenvolvimento industrial, tecnológico e também militar do país, buscou adaptar algumas palavras-chaves e outras expressões da cibernética ocidental a padrões mais bem aceitos pelo materialismo dialético, tal como oficializado na URSS: mecanismo de feedback, por exemplo, tornou-se teoria do feedback; modelos cibernéticos do pensamento tornou-se teoria dos processos lógicos de auto-organização, etc. (PETERS, 20I2). Embora revestida de um palavreado materialista-dialético, a cibernética soviética permanecia nos limites da sua dimensão matemática, logo, lógico-formal, própria para aplicações tecnológicas, conforme a concepção oriunda dos Estados Unidos. Por outro lado, seus defensores buscavam demonstrar que, de algum modo, o pensamento de Norbert Wiener, sem dúvida humanista, dialogava com o materialismo dialético oficial. Entre os nomes que lideraram a introdução e desenvolvimento da cibernética e da teoria da informação na União Soviética, citam-se Anatoliy Kitov, Alexei Lyapunov, Serguei Sobolev, Aksel Berg, Andrei Kolmogorov. Nenhum desses nomes, porém, aparece explicitamente no livro de Vieira Pinto. Devido ao seu próprio estilo de escrita, pouco preocupado com referências bibliográficas conforme normalmente praticado hoje em dia no discurso acadêmico, não raro apenas se referindo a "tratadistas", "especialistas", sem citá-los nominalmente, é difícil sabermos se ele terá tido algum acesso à obra e pensamento desses autores. Ao se referir à abordagem da cibernética no Leste Europeu, Vieira Pinto apenas cita e comenta, não raro com muitas reservas, Georg Klaus (I9I2-I974), um alemão oriental que publicou, entre outros títulos, um Dicionário de cibernética.

Além de Klaus, Vieira Pinto, em algum momento, se refere também a um livro de Jacques Guillaumaud, Cibernética e materialismo dialético, publicado no Brasil em 1970 (GUILLAUMAUD, 1970). Apesar do título, Guillaumaud nada mais faz do que divulgar, em linguagem acessível aos não iniciados, nesse aspecto sendo realmente muito didático, os princípios da cibernética e da teoria da informação como tinham sido formulados pelos seus primeiros teóricos: Shannon, Wiener, Ashby (1970), Brillouin (1988) etc. No último capítulo, ele tenta aproximar essa exposição aos princí- 
pios do materialismo dialético, a rigor apenas defendendo a possibilidade dessa aproximação. Ou seja, parece adotar a mesma atitude dos cientistas soviéticos, no seu caso numa posição mais de divulgador, ou propagandista, do que de formulador.

Outro autor marxista, já na década 1980, que sublinhará as dimensões teórica e política dessas teorias será o francês Henri Lefebvre. Mas igualmente não ultrapassará os limites lógico-formais da teoria matemática. Dirá: "há uma teoria da informação" (LEFEBVRE, 1986, p. 5I). Referia-se à de Shannon. Daí: a "teoria se desenvolve matematicamente [...]. O informacional é reconhecido, através da sua quantificação e da sua medida, como uma forma" (p. 52, grifos originais). Pois Vieira Pinto, conforme poderemos constatar nas linhas adiante, muito além: acusou e superou a lógica formal dominante nessas teorias, apresentando-nos conceitos que podiam ser considerados então inéditos. Conceitos similares, fora do Brasil, sem contato, porém, com o pensamento de Vieira Pinto (e vice-versa), podemos encontrar em alguns poucos autores na Europa ou nos Estados Unidos, a exemplo de Anthony Wilden, um pensador dialético quase nada conhecido entre nós, cujo estudo mais citado data de I972 (WILDEN, 1980); ou do biólogo Henri Atlan, cujo livro mais comentado é de 1979 (ATLAN, 1992).

Este artigo não abordará toda a trajetória intelectual de Vieira Pinto, logo também não tratará de suas contribuições específicas ao Iseb e ao pensamento desenvolvimentista. Este artigo pretende trazer o isebiano Vieira Pinto para o nosso tempo; mostrar que a atual redescoberta de Vieira Pinto, se podemos dizer assim, dá-se num momento muito oportuno: no momento exato em que, diante das questões sociais, econômicas e, por isso, também filosóficas que agendam — agora sim! — o debate na nossa sociedade capitalista atual, alcançar uma correta compreensão dialético-materialista do conceito de informação torna-se uma tarefa essencial, e, para essa tarefa, Vieira Pinto, para a nossa sorte, nos abriu uma enorme porteira para o caminho que podemos e devemos trilhar.

\section{CONTEXTO TEÓRICO (ANOS 1940-1970)}

Quem viu o filme Jogo de imitação (The imitation game), de Morten Tyldum, lançado em 20I4, pode ter percebido que, durante a Segunda Guerra Mundial, na Inglaterra, um grupo de cientistas, liderados por Alan Turing, é literalmente isolado da sociedade num laboratório secreto dentro de uma base da Marinha para buscar a solução de um problema que atormentava a liderança militar: quebrar os códigos nazistas de comunicação. A solução encontrada por Turing foi criar e desenvolver uma máquina capaz de executar essa tarefa numa velocidade tal impossível de ser atingida por um cérebro humano. $O$ filme narra um fato que, durante aquela guerra, vinha acontecendo também nos Estados Unidos e na Alemanha: cabeças brilhantes eram reunidas e isoladas em laboratórios secretos para projetar e desenvolver máquinas capazes de realizar, em altíssima velocidade, cálculos que resolvessem problemas 

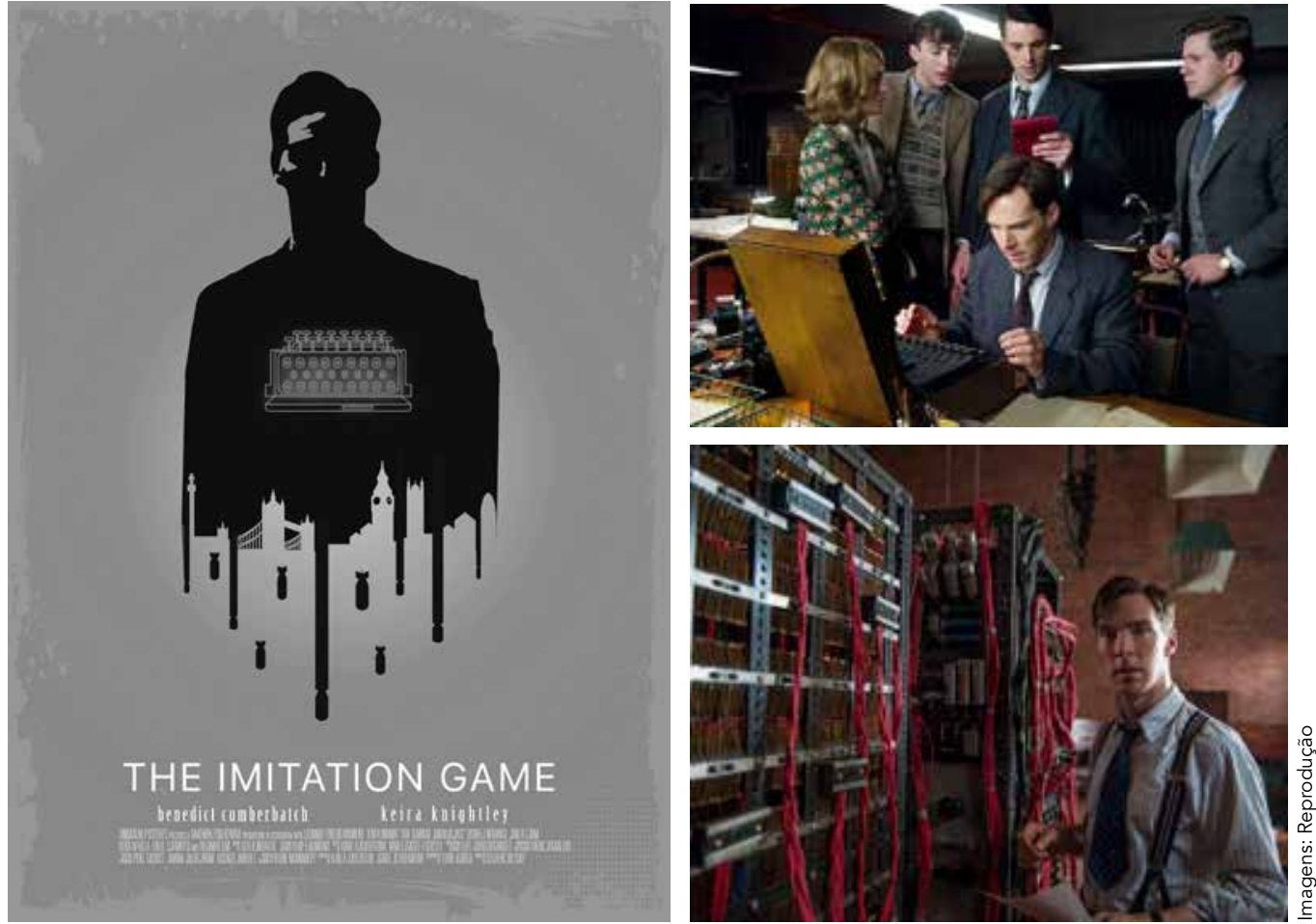

Cartaz e cenas do filme The imitation game (O jogo da imitação), de 2014, dirigido por Morten Tyldum

de criptografia, aerodinâmica, balística, inclusive os cálculos relacionados às bombas atômicas lançadas sobre Hiroshima e Nagasaki³.

Essa concentração de cérebros - físicos, matemáticos, engenheiros, inclusive poucas, mas decisivas mulheres - em espaços limitados, dedicação exclusiva, orçamentos generosos, não somente permitiu, num tempo relativamente curto, dar início a uma revolução tecnológica com o desenvolvimento dos primeiros computadores como fez nascer uma nova teoria e uma toda nova disciplina científica: a teoria da informação e a cibernética, anunciadas ao mundo pelos textos, já citados, de Shannon e Wiener.

Esses textos produziram um forte impacto nas comunidades científicas, não apenas as comunidades matemáticas, mas também aquelas que reuniam diferentes ramos das ciências sociais e humanidades: antropologia, linguística, sociologia, economia etc. Conferências, colóquios, seminários interdisciplinares são organizados para debater os impactos dessas novas teorias nos diferentes campos de saber. Umas das mais conhecidas e de grandes consequências foram as "Conferências Macy", realizadas entre 1946 e 1953 (DUPUY, 1995).

\footnotetext{
Hoje em dia, há farta documentação na internet para quem queira conhecer história da computação e informática. Para abordagens interpretativas críticas, considerando menos os aspectos anedóticos e mais as relações políticas, econômicas e ideológicas, para o português brasileiro, podemos recorrer a Breton (1991) e Mattelart (2001).
} 


\section{Não vivemos, enfatiza Vieira Pinto, \\ uma "era tecnológica", pois todas \\ as épocas foram tecnológicas, \\ nas condições possíveis e, \\ principalmente, necessárias}

Paralelamente, avançava em todo o mundo industrial um crescente processo de automação da produção, agora acelerada pelo advento daquelas novas tecnologias, bem como pela expansão de um amplo conjunto de indústrias calcadas no conhecimento científico e tecnológico: química, farmacêutica, eletroeletrônica etc. $O$ poder destruidor das tecnologias empregadas na Segunda Guerra, bem como a ubíqua presença de produtos científico-tecnológicos na vida cotidiana a partir dos anos 1950-1960, suscitaram um amplo debate intelectual no qual pensadores pareciam se dividir entre aqueles que viam nesses avanços um crescente processo de "desumanização" do ser humano e aqueles que, ao contrário, entendiam-nos como caminho para uma crescente "libertação" da humanidade. Nesse debate Vieira Pinto intervém com Ciência e existência e, principalmente, com $O$ conceito de tecnologia, tomando distância tanto dos "apocalípticos" quanto dos "integrados", como poderia dizer Umberto Eco. As sociedades humanas, desde quando os primatas começam a evoluir para a espécie humana, sempre produziram suas técnicas e desenvolveram suas tecnologias adequadas a cada estágio da evolução biológica e social. O que distingue a espécie humana das outras espécies animais é essa relação constitutiva com a técnica e suas tecnologias.

O ser humano vive em contradição com a natureza. Como qualquer outro animal, extrai da natureza suas condições de sobrevivência, mas, como nenhum outro animal, ele também produz essas condições, não depende apenas dos recursos que um nicho ecológico qualquer pode oferecer ou ao qual pode se adaptar. O ser humano adapta-se ao ambiente, adaptando a si esse ambiente. Essa é a sua natureza enquanto espécie, ou, na linguagem de Vieira Pinto, tal é o existencial da espécie humana. Por isso e para isso, o animal humano é um ser técnico: a técnica e, dela, as tecnologias que produz constituem a mediação básica da sua relação contraditória com a natureza. Não estão "fora" da humanidade, não são como que "forças" vindas sabe-se lá de onde para "dominá-la" ou "libertá-la"; são tão constitutivas e características da espécie quanto (com permissão para a pobre analogia) a tromba o é dos elefantes. A diferença - óbvia - é que a tromba é parte do corpo, não age além do corpo, já a técnica é projeção do corpo produzida por um cérebro evoluído, pela seleção natural, para tornar-se capaz de efetuar tal projeção sobre o ambiente que o cerca e sobre o mundo em que vive. Portanto, não vivemos, enfatiza Vieira Pinto, uma "era tecnológica", pois todas as épocas foram 

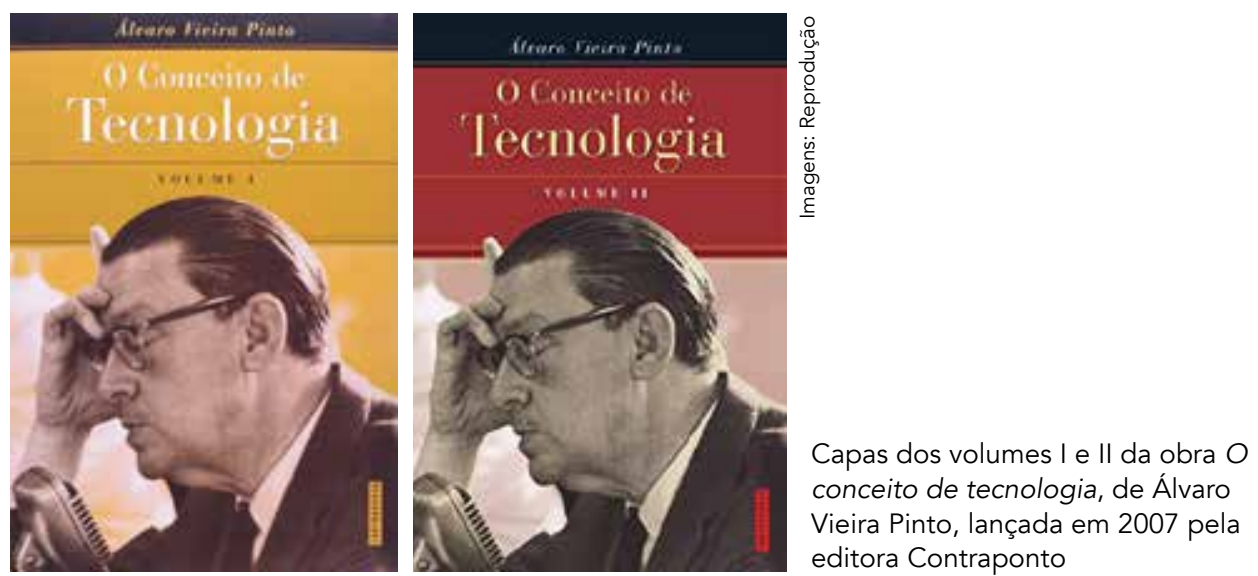

tecnológicas, nas condições possíveis e, principalmente, necessárias; e todos os povos e grupos humanos são tecnológicos, desde os ainda sobreviventes originários até os mais "desenvolvidos", considerando-se suas demandas e necessidades.

A cibernética seria uma nova etapa nessa evolução em direção à humanização do ser humano. Seu potencial heurístico provocaria novos desdobramentos nas diferentes ciências naturais e sociais. Igualmente, a informação começa a ganhar status epistemológico na medida em que a teoria de Shannon demonstra que seria possível entendê-la, com rigor científico, para além das definições de senso comum - como aquela enunciada por Porat, citado acima. Porat precisou de uma definição porque estava investigando um fenômeno social e econômico que podia ser entendido como "economia da informação": ele foi o primeiro a produzir um quadro estatístico amplo da economia dos Estados Unidos, no qual calculava o tamanho, no PIB, do setor "informacional". Além dele, outros economistas e sociólogos, ligados ao mainstream intelectual dos Estados Unidos, também vinham investigando o tema: Arrow (1962), Machlup (1962), Bell (1973). E não só eles: em obra original de 1969, o sociólogo marxista tcheco Radovan Richta, em estudo seminal sobre as transformações científico-tecnológicas que já então avançavam nas sociedades industrializadas (capitalistas ou socialistas), reconhecia o lugar determinante que a "informação" passaria a ocupar na sociedade:

Considerando-se que a informação é portadora de cada inovação e degrau intermediário necessário de cada aplicação da ciência, o desenvolvimento da informação pertence aos pilares da revolução científico-técnica (RICHTA, I97I, p. 266).

Mas... o que é informação? Sabemos, é uma palavra polissêmica. O senso comum, normalmente, a identifica com "dados", "notícia", "algo comunicado" etc. Não era essa a definição que lhe deu Shannon em livro escrito com Weaver (1975, p. 53): é redução de incerteza oferecida quando se obtém resposta a uma pergunta. Por incerteza entende-se a quantidade de respostas possíveis, dado um conjunto de possibilidades. Logo, informação é uma medida de incerteza. 
Expliquemos. No jogo de cara e coroa, só existe uma resposta possível: ou cara ou coroa. A resposta, em si, não interessa. Interessa que uma resposta, qualquer que seja, foi obtida após jogada a moeda. Nesse caso, diremos que o jogo de cara e coroa contém I bit de informação. O bit é a unidade de medida da informação, assim como o metro é a da distância; o quilo, a do peso etc. Já num jogo de dados, são 6 possíveis respostas, todas igualmente prováveis (se o dado não estiver "viciado"). Lançado o dado, qualquer resposta, não importa a alegria do jogador vencedor ou a tristeza do perdedor, conterá 2,585 bits de informação. Evidentemente, as questões que a teoria pretende resolver não são assim tão simplórias: para resolver seus reais problemas, ela apoia-se num conjunto de equações bayesianas. Importante, em termos epistemológicos, é registrar que, nessa teoria, não há história nem tempo. O resultado "5" num lance de dado, por exemplo, não é consequência nem causa de algum resultado anterior ou posterior. O tempo ou distância que a moeda pode percorrer, uma vez lançada, não altera a quantidade de informação: I bit. A informação só pode ser medida se sabemos a quantidade de eventos passíveis de ocorrer (I evento entre 2, I evento entre 6 etc.), bem como as relações probabilísticas entre eles (nos dois exemplos, os eventos são equiprováveis, mas na grande maioria dos casos não será assim).

A teoria de Shannon é lógico-formal. Também a de Wiener. Nascidas na engenharia, seria "natural", digamos assim, que trouxessem esse vício de origem. Em Shannon, a mensagem transmitida de uma fonte emissora deve chegar ao seu receptor com a mesma qualidade inicial, ou seja, sem perda de quantidade. O que pode provocar perda de quantidade com destruição de qualidade são interferências indesejadas no canal de transmissão, interferências que Shannon denomina, muito apropriadamente, "ruídos" (noise). Em termos aristotélicos, o "ruído" é o terceiro excluído. No modelo shannoniano, os "ruídos" devem ser filtrados, reprimidos. Ou seja, nesse modelo não há lugar para a contradição ${ }^{4}$.

No modelo de Shannon, "emissor" e "receptor" parecem atados por um canal, este que lhes serve para a comunicação. É típico modelo de telecomunicações, objeto das suas pesquisas5. O "receptor" parece passivo, aceitando a mensagem. Se responde, então se inverte a direção da comunicação, ele agora é "emissor", e o outro, "receptor". Trata-se de um mecanismo de retroação, ou feedback, que, epistemologicamente, distingue o sujeito do objeto - dualismo cartesiano, conforme explica Sfez (I994).

\footnotetext{
4 Aristóteles fixou três princípios lógicos, muitas vezes entendidos como "leis do pensamento", segundo os quais: 1) "se qualquer enunciado é verdadeiro, então ele é verdadeiro" (princípio da identidade); 2) "nenhum enunciado pode ser verdadeiro e falso" (princípio da não contradição); 3) "um enunciado ou é verdadeiro ou é falso" (princípio do terceiro excluído) (apud COPI, 1981). Esses são princípios basilares em toda a construção da lógica formal. No modelo de Shannon, por exemplo, construído sobre a lógica binária 1 = mensagem / 0 = não mensagem, qualquer outro evento que aportaria ambiguidade à possível mensagem deve ser filtrado, neutralizado, excluído. A lógica formal, distintamente da lógica dialética, não aceita a contradição.

Claude Shannon (1916-2001) trabalhava nos Laboratórios Bell (Bell Labs), mantidos pela American Telephone \& Telegraph (AT\&T), que, desde os anos 1910 até a década de 1980, detinha o monopólio da telefonia nos Estados Unidos. Era um centro de pesquisas científicas e tecnológicas do qual saíram importantes inovações em telecomunicações ou mesmo invenções, a mais importante tendo sido a do transístor, anunciado ao mundo em 1948.
} 
Em 1965, num dos anuais colóquios de Royaumont, o sociólogo marxista francês Lucien Goldmann apresentou o seu conceito de consciência possível, tentando explicá-lo à luz do que entendia como conceito de informação: "Parece-me que informação significa transmissão de um certo número de mensagens, de afirmações verdadeiras ou falsas, a um indivíduo que as recebe, as deforma, as aceita ou as rechaça, ou ainda pode permanecer completamente surdo e refratário a toda recepção." (GOLDMANN, 1970, p.4I)

Nos debates que se seguiram à palestra, vários participantes não esconderam o desconforto e até irritação com o enfoque dado por Goldmann ao conceito de informação. Lá pelas tantas, ele teve de anuir um tanto pateticamente: "Tem muita razão. Eu disse que falaria do receptor e não do emissor. Você diz que isso não concerne ao estado atual da teoria da informação. Eu não sei nada disso." Em socorro de Goldmann acorreu o biólogo Fessard, reivindicando a ampliação do conceito para além do seu estrito significado físico: "Para mim, o conceito de informação é puramente relativo à qualidade que possui o receptor para decifrar a informação." Insistiu: "Creio que a quantidade de informação não tem sentido maior, exceto na medida em que exista um receptor capaz de decifrá-la." (GOLDMANN, I970, p.4I)

Não deve ter sido casual — sendo até sintomático porque, tudo indica, foi involuntário - que um intelectual marxista fosse dos primeiros a levantar o problema do "receptor" na teoria da informação. Dialeticamente, não podemos entender o processo informacional sem a presença de pelo menos um agente ativo, aquele que busca e, porque busca, recebe a informação. O "receptor" é quem necessita obter a notícia emitida pelo locutor de televisão ou rádio, é quem procura, se for um arqueólogo, os indícios arqueológicos em alguma antiga cultura. Numa abordagem dualista, seria pois o "receptor" quem atribuiria significados à mensagem encaminhada pelo "emissor".

Implica dizer que o "receptor", ao acolher ou não a mensagem, não somente precisa estar "interessado" nela como precisa inseri-la nas suas próprias condições psicológicas, subjetivas, semânticas, de acordo com o seu grau de cultura e as suas expectativas. Qualquer mensagem está carregada de "ruídos", alguns muito concretos, como os barulhos físicos do ambiente à volta; outros, pelas condições mentais, intelectuais dos interlocutores. A seleção desses "ruídos" é que dará a real significação à mensagem, tanto da parte do "receptor" quanto também do "emissor". O assim chamado "emissor" sempre buscará enviar mensagem na qual já sabe, de antemão, ou pode presumir, que o "receptor" estará interessado, e em condições de a receber. Para professores, por exemplo, esse conhecimento presumível embasa o que denominamos "didática". Ou seja, toda comunicação não está encerrada em um canal, conforme o famoso, mas limitado, modelo de Shannon; antes, se efetua em algum ambiente mais amplo, ou sistema (social, biológico, físico) no qual a "emissão é imediatamente recepção; recepção é imediatamente emissão" (DANTAS, 20I2, p. 36). Ou, como escreveu Marx: "a produção é imediatamente consumo e o consumo é imediatamente produção" (MARX, 20II, p. 46). A relação imediata aí não é, claro, temporal, mas dialética. O tempo entre o processo de produção e o de consumo, assim como entre o processo de emissão e de recepção, pode 
até ser demorado, devido a barreiras espaciais ou outras. Mas, independentemente de qualquer distância de tempo e espaço, a relação produtor-consumidor (ou emissor-receptor) já está dada a priori, no ato mesmo da produção ou de seu consumo, porque está determinada pelos valores de alguma cultura, valores esses que se sobrepõem às decisões ou condições meramente econômicas ou tecnológicas: o McDonald's, por exemplo, não vende sanduíche de carne de vaca na Índia. Antes de produzir o seu sanduíche e, com ele, "emitir" suas mensagens comportamentais, já foi o "receptor", que, com base em outros "ruídos", soube adaptar-se ao "sistema". Quem "emite" já espera as ações de quem "recebe" e já se adapta a elas; quem "recebe" já espera as ações de quem "emite" e a elas já se ajusta; ambos nos contextos e circunstâncias da própria ação na qual estão interagindo. Escarpit (199I), cientista da informação francês, marxista, denominará esse modelo pelo acrônimo "eme-rec" (émetteur-récepteur).

Portanto, o "ruído" não está mais excluído; ele é inerente ao processo, cabendo aos polos em interação selecionar aqueles eventos que favorecem ou enriquecem a ação comunicativa; e aqueles que podem atrapalhá-la ou prejudicá-la. Foerster (I960) e Atlan (1992), a partir dessa constatação, vão sugerir, respectivamente, os modelos de "ordem pelo ruído" e "organização pelo ruído": o assim chamado "ruído" passa a ser entendido como qualquer evento passível de ocorrer no sistema que afeta a comunicação, de modo a produzir ajustes que não são necessariamente negativos, ao contrário: os ajustes, na maior parte das vezes, aprimoram, pela experiência e aprendizado, o sistema e os atores em seu interior. "Aprende-se errando", diz a sabedoria popular. Exatamente assim, aprendendo com os "ruídos", os seres vivos sobrevivem, crescem, se reproduzem, evoluem, embora, mais cedo ou mais tarde, cada um dos indivíduos morra.

A teoria matemática, probabilística, apenas se interessava pela medida, ou quantidade, da informação. Mas será a partir dela, quer dizer, a partir dessa possibili- 
dade por ela aberta de se obter um conceito científico, objetivo, rigoroso, de informação, que cientistas vindos de outras formações vão encontrar soluções que, sem ofender o rigor da lógica, acrescentam-lhe movimento, tempo e história. Em Shannon, a informação deve ser intercambiada nas mesmas quantidades, como valor de troca. Mas seu valor de uso residirá nos ganhos em significações que lhe podem aportar os "ruídos", ou seja, não na igualação, na equivalência, mas, ao contrário, na diferença, como sentencia Bateson (I998, p. 407): informação é “diferença que cria diferença”.

Não por acaso, esses cientistas vieram dos campos da biologia, da sociologia, da linguística, entre outros, ou seja, dos campos que passaram a compreender a informação como uma relação essencial do movimento, evolução, transformação da matéria viva: aquela definição de Vieira Pinto, que apresentamos logo na primeira linha deste artigo.

Com eles terá início o movimento que Dupuy (1995) denomina "segunda cibernética”. É (quase) certo que Vieira Pinto não tenha tomado conhecimento desse movimento. Sua crítica é toda dirigida aos autores da "primeira cibernética", o que torna ainda mais relevante e mesmo fundador o seu pensamento: um teórico solitário, sobrevivendo de traduções no Brasil sob a ditadura, nos primeiros anos I970. Uma mente poderosa que soube superar essas limitações e nos legar, no campo marxista, uma teoria sem antecedentes, até onde se sabe, quando a elaborou e escreveu.

\section{INFORMAÇ̃̃O, FORMA DO MOVIMENTO DA MATÉRIA}

O primeiro e central ponto que devemos destacar no pensamento de Vieira Pinto, embora sem surpresa, é sua ênfase na materialidade da informação.

Temos de ir às formas mais gerais do movimento da matéria, às reações inorgânicas do mundo físico, depois, já em plano mais complexo, às formas de relacionamento da matéria tornada viva, nos seres vegetais e [animais] ${ }^{6}$, subindo em escala progressiva de complexidade e clareza relativas até a completa realização na condição existencial do ser humano na esfera da consciência (VIEIRA PINTO, 2005, p. 31).

Vieira Pinto reconhecerá a informação "como fato originariamente material e secundariamente subjetivo" (VIEIRA PINTO, 2005, p. 3I). A informação existe "na qualidade de forma geral do movimento da matéria", daqui se extraindo o "conceito particular enquanto existencial do homem" (p. 32). A informação se encontra nos três estágios em que a matéria está organizada: o inorgânico, o orgânico e o humano, ou cultural. Em síntese, para Vieira Pinto,

a informação é pois um conceito sintético, válido para todas as formas de movimento da matéria e portanto, naturalmente, para a mais complexa e perfeita, o pensamento (VIEIRA PINTO, 2005, p. 32).

Na edição da Contraponto, nesta passagem lê-se "matéria tornada viva, nos seres vegetais e minerais". Há um evidente erro aí, que pode ter origem num descuido na transcrição ou revisão; ou do próprio autor, ao crivo de sua revisão final. Vieira Pinto só pode estar se referindo nessa passagem a vegetais e animais. 
Ou ainda:

A informação não se identifica com uma propriedade, mas com uma forma do movimento da matéria (VIEIRA PINTO, 2005, p. 379).

Foi necessário o desenvolvimento teórico, embora suportado em toda a evolução tecnológica e, não raro, com ela confundido (como tantas vezes vai apontar Vieira Pinto), para chegarmos a essa constatação epistemológica da dimensão informacional da vida material. Observou Abraham Moles, numa obra original de 1973, que

a tomada de consciência da materialidade da informação é extremamente recente. Não faz muito tempo, o aspecto ideal das mensagens interpessoais passava tão evidentemente ao primeiro plano que deixava na sombra o aspecto material. As ideias que se "transmitiam" faziam esquecer a transmissão. Para Platão, Bacon ou Espinosa, a materialidade da escrita não era outra coisa senão contingência acessória da qual justamente convinha libertar o pensamento, e o mito das palavras geladas do terceiro livro de Pantagruel não era mais que um amável conto desprovido de valor filosófico (MOLES, 1978, p. 27I-272).

Marx e Engels parecem justamente ironizar essa "contingência acessória" que provavelmente ainda muito perturbava os filósofos de seu tempo, quando escrevem:

depois de já termos examinado quatro momentos, quatro aspectos das relações históricas originárias, descobrimos que o homem tem "consciência". Mas esta também não é, desde o início, consciência "pura”. O "espírito" sofre, desde o início, a maldição de estar "contaminado" pela matéria, que, aqui, se manifesta sob a forma de camadas de ar em movimento, de sons, em suma, sob a forma de linguagem (MARX; ENGELS, 2007, p. 34-35).

Surpreende, assim, que, após tal avanço epistemológico e teórico, vivamos hoje num tempo quando pensadores críticos em geral e, em particular, teóricos que se pretendem marxistas ou marxianos venham nos falar de um trabalho "imaterial", ou de uma economia "imaterial"...

Para Vieira Pinto, no mundo físico inorgânico, entende-se por informação as relações que os elementos estabelecem entre si, afetando-se e se transformando mutuamente. Em termos de uma dialética que nos remete a Engels, trata-se do próprio princípio da ação recíproca, ao qual Vieira Pinto retorna amiúde, inclusive nos introduzindo em uma nova e criativa leitura do princípio cibernético da retroação. No universo inorgânico não ocorre, por óbvio, um processo consciente, mas processos regidos pelas forças conhecidas da física e da química. Um átomo que captura elétron de outro átomo terá nisso também "informado" a si e ao outro átomo uma nova relação eletrônica entre eles, e provocado as reações cabíveis nos termos da física. Se as leis e forças determinam as possibilidades e limites dessas relações, o movimento em si, a transformação em si, a nova relação em si, caracterizaria a presença da informação na matéria. Trata-se de um processo permanente e inesgotável de mudança e movimento no Universo. 
Em tal sentido, a informação está por toda a parte e conduz à organização, ou melhor, exprime-se nela. Conduz à organização porque a condição para que esta se institua consiste em que, espontânea ou artificialmente, as partes da matéria se estruturem segundo as qualidades imanentes a elas e em obediência às leis gerais que presidem a possibilidade de tal união, em função das ações recíprocas exercidas umas sobre as outras (VIEIRA PINTO, 2005, p. 38I).

Ou seja, no conceito de informação, encontramos o princípio da organização da matéria, apontado por muitos outros autores, dialéticos ou não. O psicólogo matemático Anatol Rapoport (I9II-2007), por exemplo, resume:

Se a energia tinha sido o conceito unificador subjacente a todos os fenômenos físicos que supunham trabalho e calor, a informação tornou-se o conceito unificador subjacente ao funcionamento dos sistemas organizados, isto é, sistemas cujo comportamento era controlado de modo a atingir alguns objetivos pré-estabelecidos (RAPOPORT, 1976, p. 29).

No entanto, prosseguirá Vieira Pinto, não será nesse "nível elementar e inorgânico que o conceito de informação manifesta sua completa utilidade" para constituir uma teoria filosófica (VIEIRA PINTO, 2005, p. 3I). À teoria interessará a informação consciente. Porém, para chegar aí, no seu processo evolutivo, a matéria faz-se orgânica e dá origem à vida. Aqui, a informação já adquire um caráter teleonômico (embora Vieira Pinto não utilize esse termo): ela se encontra nas relações dos seres vivos entre si, em suas lides de sobrevivência e reprodução.

A informação, fundada igualmente na experiência que lhe é possível, encontra-se também em todas as espécies animais e até nos vegetais, no sentido de a matéria viva componente de qualquer ser animado estar obrigada a praticar escolha fundamental entre os elementos do meio de que se utiliza para nutrir-se, e portanto sustentar o ciclo de substituição da matéria que conserva por algum tempo a estrutura dos entes vivos. Com efeito, um ser vivente só é tal porque se mostra capaz de recolher do meio os constituintes materiais que irá incorporar à sua estrutura em qualidade de fontes de energia e elementos de reposição, a fim de reparar as perdas sofridas com o metabolismo natural do processo vital. Tem igualmente de praticar outras escolhas essenciais à perpetuação da vida, entre elas a busca do habitat conveniente e a procura e reconhecimento do parceiro sexual, nas espécies não hermafroditas ou dioicas. Nesse sentido, pode-se dizer que a matéria, mesmo organizada em nível infra-humano, executa um circuito informativo (VIEIRA PINTO, 2005, p. 206-207).

Ainda nos falta chegar à informação consciente, sem a qual não haverá projeto. O animal é movido pelos seus instintos, geneticamente determinados. Só no nível humano a matéria está organizada para incorporar a informação a um "projeto de ação", a uma experiência que possa transcender as limitações das leis naturais ou 
biológicas. Aqui, Vieira Pinto sobe do nível teleonômico próprio de toda matéria biológica para o nível teleológico, exclusivo da espécie humana:

a informação apresenta como aspecto supremamente distintivo o caráter social. Resulta da posse simultânea da informação por via biológica, aspecto pelo qual se iguala a qualquer outro animal, e por via cultural, significando a criação de canais informativos peculiares à espécie (VIEIRA PINTO, 2005, p. 206-207).

Logo,

o tipo de informação que o homem produz e comunica a um semelhante é de categoria original, não tem antecedentes na escala zoológica e pode ser o conhecimento abstrato, teórico, imaginativo, livremente elaborado por uma consciência que se interessa em transmiti-lo a outra (VIEIRA PINTO, 2005, p. 243).

Vieira Pinto nos introduzirá em uma determinação peculiar à informação social: ela não pode escapar das condições de disputa, contradições e história da própria humanidade. A informação será distribuída conforme a "desigualdade interna à espécie" (VIEIRA PINTO, 2005, p. 242). As sensações de calor ou frio, por exemplo, serão diferentes para quem disponha, ou não, dadas as suas condições de renda ou posição de classe, de aparelhos de calefação ou de ar condicionado. A informação social, pois, adquire um caráter sociológico de classe.

Essa informação social é, em uma palavra, linguagem, a forma exclusivamente humana de captar, processar, registrar, comunicar informação. Na linguagem, a informação se torna portadora de "sentido inteligível, já então socialmente fixado, e não mais espontâneo, arbitrário" (VIEIRA PINTO, 2005, p. 248). Então, a transmissão, por exemplo, dos sons da fala pelo ar ou, mais tarde, por instrumentos de comunicação a distância, mediante transformação de energia sonora mecânica em impulsos eletromagnéticos,

muda de qualidade, deixa de ser simples fenômeno físico para se carregar de sentido propriamente humano, isto é, existencial, em vista de exigir a referência às relações sociais de produção. $\mathrm{O}$ que era em totalidade ruído passa a ser mensagem dotada de conteúdo semântico e trazendo na qualidade de franja marginal cada vez mais reduzida a característica de "ruído" (VIEIRA PINTO, 2005, p. 248).

E assim, ao longo de ampla e profunda elaboração da qual aqui só captamos alguns traços essenciais, Vieira Pinto chega finalmente ao que podemos considerar a sua definição de informação:

A informação define o aspecto abstrato pelo qual aprendemos em forma mais geral o exercício contínuo da atividade prática do homem que opera sobre o mundo, resolvendo sua contradição fundamental com ele a fim de produzir 
os meios para sobreviver. Não tem origem anterior ao surgimento da matéria viva, a não ser em forma de ações recíprocas puramente inorgânicas, e no homem se confunde com o desempenho da atividade racional. Sabemos que esta consiste em pensar os dados da realidade e com eles conceber os meios de transformá-la. Por esse motivo a informação apresenta-se sob o duplo aspecto de aquisição de dados objetivos e de atividade de transformação das estruturas materiais e sociais da realidade (VIEIRA PINTO, 2005, p. 365, grifos nossos).

Sublinhemos estas passagens: informação "se confunde com o desempenho da atividade racional"; é "aquisição"; é “atividade de transformação". É movimento. Logo, só pode ser trabalho. Vieira Pinto nos sugere essa imbricação entre informação e trabalho, embora, nessa passagem, não chegue a afirmá-lo com todas as letras. Trabalho material, bem entendido.

O conceito de trabalho e toda a condição ontológica e gnosiológica do ser humano como produto e produtor do seu trabalho era o eixo que orientava a produção intelectual de Vieira Pinto, por esse eixo tendo ele chegado a este seu grande tratado póstumo, O conceito de tecnologia. Ora, se ele nos diz que a informação constitui-se no próprio "ser existencial do homem" (VIEIRA PINTO, 2005, p. 3I), e assim também entendemos o trabalho, a simbiose é lógica. Informação não nos é algo "externo", como "dados organizados" ou "conhecimento transmitido"; não é um objeto, mas é a própria relação viva de nosso ser biológico e cultural com o nosso ambiente natural e social: relação ativa, transformadora.

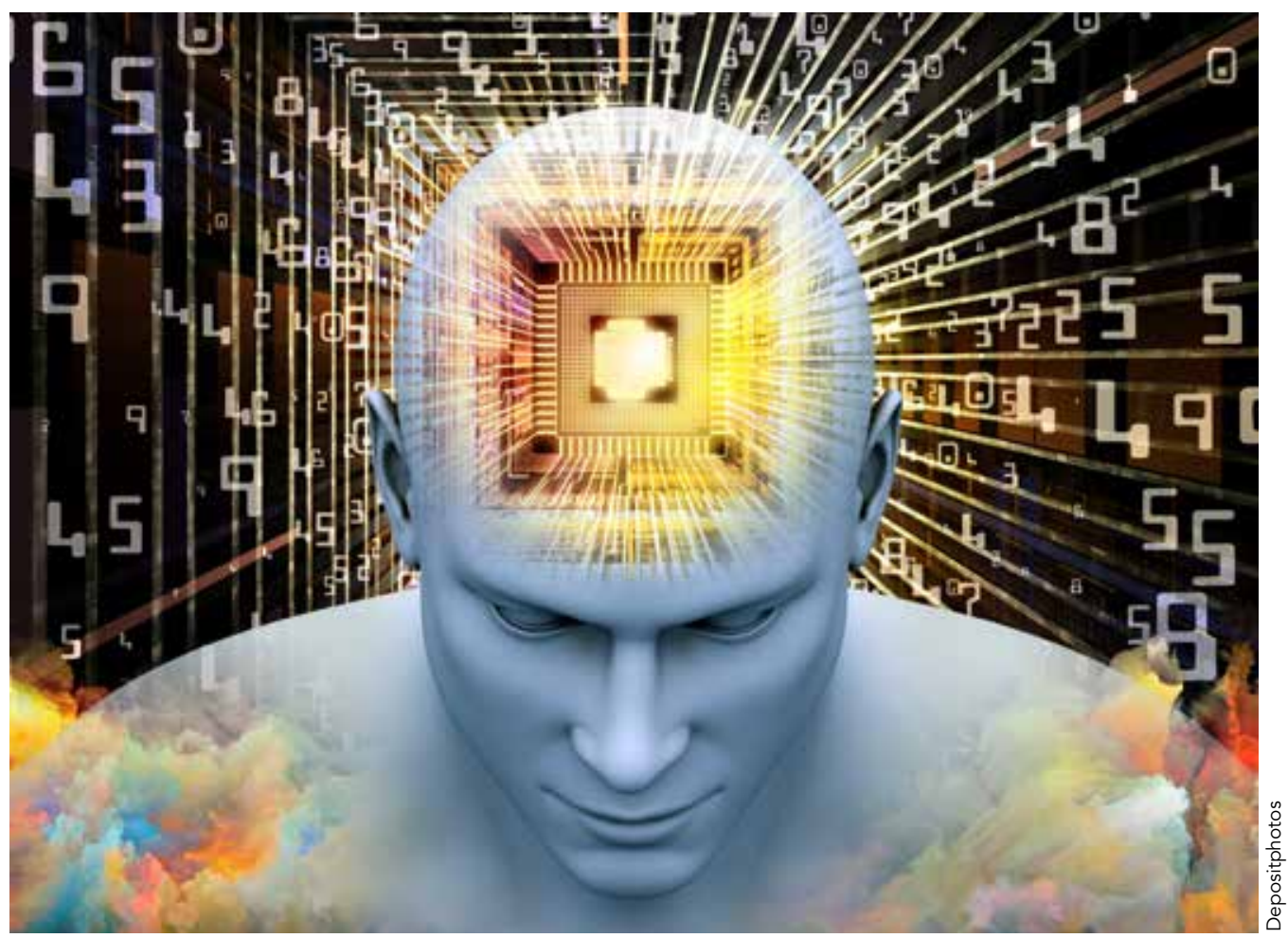


O que Vieira Pinto afirma não estaria em desacordo, por exemplo, com o pensamento de Heinz von Foerster, um dos pioneiros da "segunda cibernética":

O que atravessa o cabo não é informação, mas sinais. No entanto, quando pensamos no que seja informação, acreditamos que podemos comprimi-la, processá-la, retalhá-la. Acreditamos que informação possa ser estocada e, daí, recuperada. Veja-se uma biblioteca, normalmente encarada como um sistema de estocagem e recuperação de informação. Trata-se de um erro. A biblioteca pode estocar livros, microfichas, documentos, filmes, fotografias, catálogos, mas não estoca informação. Podemos caminhar por dentro da biblioteca e nenhuma informação nos será fornecida. $O$ único modo de se obter uma informação em uma biblioteca é olhando para os seus livros, microfichas, documentos etc. Poderíamos também dizer que uma garagem estoca e recupera um sistema de transporte. Nos dois casos, os veículos potenciais (para o transporte ou para a informação) estariam sendo confundidos com as coisas que podem fazer somente quando alguém os faz fazê-las. Alguém tem de fazê-lo. Eles não fazem nada (FOERSTER, 1980, p. 19, grifos originais).

Em suma, alguém tem de... trabalhar.

\section{DIALÉTICA DO "RUIIDO"}

\section{Examinando o princípio cibernético do feedback, dirá Vieira Pinto:}

$\mathrm{O}$ exame da retroação mostra a insuficiência dos quadros formais para explicá-la. Basta apontar, a título de exemplo, a impossibilidade de continuar sustentando um dos princípios tradicionais supremos, o do terceiro excluído [...]. Nas estruturas de retroação, conforme se verifica numa programação cibernética, a cada causa, além das possibilidades normais de produzir-se ou não o efeito previsto, acrescenta-se a eventualidade da ocorrência de um resultado formalmente inesperado, o retorno do efeito a qualquer dos momentos da série causal linear precedente. Esse acontecimento não significa, evidentemente, haver sido invertida a ordem do procedimento da natureza, mas indica que foi aproveitada uma das possibilidades objetivamente existentes nessa ordenação causal, apenas desconhecida pela lógica em que era concebida. A retroação sempre ocorreu a todo instante e por toda parte no mundo e na sociedade, mas foi preciso esperar que a evolução histórica do conhecimento levasse a teoria cibernética a pô-la em evidência, demonstrando-lhe o caráter de fenômeno objetivo, material. Essa conclusão tem profundas e universais consequências. Implica a necessidade de recorrer a outro instrumento lógico, o de tipo dialético (VIEIRA PINTO, 2005, p. 346).

Os "especialistas", com quem discute ou dialoga, não tinham disso se apercebido, conforme acusa Vieira Pinto logo a seguir. Mas isso que ele descreve na sua 
peculiar linguagem será similar ao princípio da organização pelo ruído, proposto por Atlan (1992), a partir de Heinz von Foerster. Não é tanto um "ruído", mas evento aleatório, imprevisto, cuja emergência pode tanto contribuir para aprimorar quanto para prejudicar a evolução do sistema, a depender das suas condições estruturais e funcionais. Assim, o aprimoramento de uma organização biológica ou social pela absorção e tratamento da aleatoriedade, dirá Atlan com todas as letras, é a negação da negação por efeito do "ruído" mesmo. Esse "ruído" já estaria no sistema, e sua potencial ocorrência, ao se dar a conhecer objetiva e praticamente, revela uma ignorância do agente sobre todas as potencialidades desse sistema. A emergência do "ruído" não pode ser resolvida pela lógica formal da "primeira cibernética", mas pode sê-lo se, no cálculo, for introduzido o tempo, ou seja, a história, por meio de equação diferencial. Esse salto quantitativo introduz nova qualidade no processo, qualidade esta que resolveria um dos mais rígidos limites da lógica de Shannon: o problema do significado. O "ruído", diz Atlan citando Brillouin (1988), revela a "informação que nos falta”, a nossa ignorância sobre todas as potencialidades do sistema, apenas tratável, a partir do momento da sua ocorrência, se ocorrer, por métodos semânticos. Numa tacada, Atlan resolveu o problema matemático da relação entre "ruído" e "mensagem" ao introduzir o tempo e mudar o campo operatório; deu a partida para entendermos a relação entre quantidade física calculável e qualidade semântica não calculável na teoria da informação; e abriu uma larga estrada para entendermos a informação conforme princípios dialéticos.

Essa estrada seria ainda mais alargada por teóricos de outros distintos segmentos de saber que Sfez (I994) sintetizaria no rótulo "comunicação expressiva", em oposição à "comunicação representativa" da "primeira cibernética". Destaque para a Escola de Palo Alto, de Gregory Bateson, Paul Watzlawick e seus colegas. Sfez, que inclui também Henri Atlan nesse mesmo grande campo epistemológico, assinala que, estranhamente, esses pesquisadores não exibem consciência do alcance epistêmico e mesmo das raízes das teorias que formularam: a "dissidência" de Espinosa e, daí, Hegel, donde, claro!, Karl Marx. Construíram as teorias que construíram com base, sobretudo, na própria experimentação empírica que lhes ia revelando os limites teóricos da "primeira cibernética" e, certamente, nos valores éticos gerais que lhes orientavam nessas práticas. Atlan, ao menos em uma entrevista, confessou que muitas pessoas faziam-lhe comentários sobre os fundamentos espinosianos de suas teorias biológicas, dos quais ele mesmo não tinha ideia. Só então foi ler Espinosa, do qual se tornaria profundo conhecedor e adepto (ATLAN, 2003).

\section{INFORMAÇ̃̃O, ENTROPIA, NEGUENTROPIA}

Não devemos fugir de um espinhoso problema em Vieira Pinto: sua aversão à hipótese da entropia. O problema remete a toda a compreensão então dominante do materialismo dialético conforme codificado na URSS.

Diz-nos Vieira Pinto que será inútil trazer à discussão, conforme opina "a maioria dos mais recentes tratadistas" (não os nomeia), as relações entre informa- 
ção e a "noção de 'entropia negativa' ou 'neguentropia', visto não propiciar nenhum resultado útil ao desenvolvimento da teoria da informação". Assegura-nos que a própria noção de entropia "é hoje uma questão em via de reexame e reformulação", não esclarecendo de onde extraiu essa proposição. Sustenta que o segundo princípio da termodinâmica estaria em conflito com o princípio dialético da "ação recíproca", logo, também pouco ajudaria na compreensão da informação e, mesmo, do Universo. Convida-nos expressamente a abandonar esse caminho que teria sido sugerido pela analogia entre a equação de Shannon para o cálculo da informação e a de Boltzmann para o cálculo probabilístico do estado entrópico das moléculas de gás em um recipiente fechado (VIEIRA PINTO, 2005, p. 180-I83, passim).

Fundamentada em umas poucas e fragmentárias observações de Engels, em Dialética da natureza, sobre as leis da termodinâmica inicialmente formuladas por Rudolf Clausius (I822-I888), consolida-se no marxismo-lenininismo a "teoria" consoante a qual a segunda lei estaria "errada" porque entrava em conflito com as "leis da dialética", especialmente a da "ação recíproca". Essa segunda lei estabelece que, num sistema fechado, o movimento tende irreversivelmente a perder sua força, o calor tende a se degradar, logo, o sistema tende a perder capacidade de fornecer trabalho e de evoluir. Assim (mal) compreendida, a segunda lei estaria em contradição com o princípio da contínua evolução da matéria, inclusive apontando para um "fim" do Universo (morte térmica do Universo), sendo, como então se imaginava, também um sistema, nos seus limites, fechado (hoje sabemos que, ao contrário, o Universo continua em expansão). Se o Universo tem fim, teria tido um "início". Quem o criou?

Não poucos autores, críticos do marxismo ou, pelo menos, da sua versão leninista, sobretudo os que, em tempos mais recentes na agenda da crise ecológica, concordam com essa interpretação, como Bensaid (2003, p. 483-487, passim) e também Martinez-Alliez, Stanley Jaki, outros e outras, citados por Foster e Burkett (2008). Estes dois autores, porém, observam que seria difícil a Marx e Engels, profundos conhecedores da ciência de seu tempo, negarem a segunda lei. Mais provavelmente, se a doutrina "oficial" consagrou essa posição, isso se deve a uma má leitura de trechos que não passam de anotações fragmentárias escritas em datas distintas e inseridas na primeira edição, póstuma, da Dialética da natureza, publicada em 1925, na União Soviética. De fato, nessas passagens, Engels se mostra incomodado com possíveis ilações teológicas que derivariam da segunda lei, mas também observa serem elas, àquela época, ainda muito recentes, daí que haveria questões então não respondidas: "é tão certo que ela [a aparente incongruência lógica da segunda lei] será resolvida quanto é certo que na natureza não sucedem milagres e que o calor original da nebulosa não lhe foi transmitido de fora do cosmo por milagre" (ENGELS, 2020, p. 306). Pouco mais de cem anos depois de escritas essas linhas, Prigogine e Stengers (1992; 1997) demonstrariam como estruturas dissipativas podem gerar movimentos contrários à entropia, de início aparentemente acidentais, e nuvens que se concentram acumulando energia, antecedendo as tempestades. 
O conceito de entropia mede o grau de evolução do sistema tendendo a chegar ao equilíbrio máximo, ou "morte térmica", se outras interações não afetarem reversivamente o processo. Como, exceto em formulações teóricas ou experiências de laboratório, será difícil imaginar um sistema realmente fechado (isolado), pois, na natureza, todos os seus elementos estão inseridos, pelo menos, em relações energéticas uns com os outros, não precisamos revogar a lei da ação recíproca para aceitar a segunda lei da termodinâmica. Mas talvez tenhamos de revogar algumas leituras mais ortodoxas...

Se o sistema tende ao equilíbrio, por óbvio se encontra em algum grau de não equilíbrio. Esse estado, sempre dinâmico, corresponde à neguentropia, conceito cunhado por Brillouin (1988) que mede a capacidade do sistema em fornecer trabalho (pode ser o operário ao chegar à fábrica, no início da sua jornada diária). A informação, demonstrou Brillouin, é o processo capaz de explicar a obtenção de neguentropia por meio de neguentropia, ou seja, é o trabalho que busca absorver energia livre no ambiente para sustentar ou recuperar um dado estado inicial de neguentropia; logo, é um processo essencial, até mesmo vital, de resistência dos organismos vivos à entropia. Vida é informação. Vieira Pinto chegou a conclusões similares, mesmo desconhecendo a "segunda cibernética" e rejeitando a relação entre informação e as leis físicas da termodinâmica.

Vivemos mergulhados em emanações de matéria-energia: frequências luminosas e sonoras, moléculas químicas odoríficas, emanações de calor etc. Para sobreviver, cada espécie animal ou vegetal dispõe de recursos perceptivos que lhe permitem selecionar e organizar em seu ambiente aquelas emanações que orientarão algum trabalho de busca e captura de matéria-energia necessária à reposição de suas condições neguentrópicas durante algum segmento de tempo: minutos, horas, dias, anos, décadas, até séculos para cada indivíduo inserido em sua diferente espécie. Nesse processo, também se está despendendo energia, mas de uma forma orientada, visando a um objetivo, que ao cabo resultará num ganho neguentrópico que não pode ser superior ao ganho entrópico (cansaço) ao longo da própria ação, mas, ao menos, deve ser suficiente para restaurar o estado neguentrópico necessário para seguir fornecendo trabalho durante mais alguns minutos, horas ou dias.

E será justo que seja o próprio Vieira Pinto quem nos confirme essa hipótese: é o que ele mostra, por exemplo, na passagem que já citamos antes sobre a informação biológica (VIEIRA PINTO, 2005, p. 206-207). Os animais, lemos naquela passagem, "estão obrigados" a efetuar "escolhas" para se nutrir, estabelecer áreas de hábitat, encontrar parceiros sexuais, tudo isso visando recuperar as "perdas sofridas com o metabolismo normal do processo vital". Essas "perdas" são justamente as regidas pelas leis da termodinâmica, em especial pela segunda lei, e tais "escolhas" são processamento de informação, conforme as emanações energéticas de que seus organismos estão constituídos para captar e selecionar (sons, cheiros, cores etc.), implicando esse processamento atividade - física, orgânica, material — de captar, relacionar, registrar, 
transmitir informação, isto é, captar, relacionar, registrar, transmitir aquelas emanações, mas, agora, postas numa relação de sentido, de objetivo, conforme justamente tudo aquilo que Vieira Pinto nos vinha explicando até aqui.

A sustentação da vida pela informação não pode, no limite, revogar a segunda lei: a neguentropia recuperada corresponderá também a ganho de entropia em algum outro segmento do sistema-ambiente: a sobrevivência do leão exige a morte da zebra. Em geral, no mundo orgânico, essa relação é apenas suficiente para manter o ser vivo em condições de continuar vivo e se reproduzir. É uma relação homeostática, de permanente negação-afirmação do equilíbrio.

Já a relação do ser humano com o ambiente vai além, pois ele, desde as mais antigas civilizações, tem capacidade de introduzir mudanças no ambiente que lhe permitem produzir excedentes, ou seja, retirar energia acima das suas necessidades vitais, movido agora por fatores sociais, históricos, culturais. Necessariamente, o sistema-ambiente produzirá ou transferirá entropia compensatória para algum outro espaço ambiental. Nessa relação homeorrética, o ser humano tem vivido historicamente mais distante do equilíbrio, num processo que, sem dúvida, foi muito acelerado e agravado pelo modo capitalista de produção que começou a se expandir mundialmente nos últimos 200 anos.

Anthony Wilden (1935-2019), um autor que, provavelmente, Vieira Pinto gostaria de ter lido, explica que percebemos a informação através de estruturas, formas, modelos, figuras e configurações; em ideias, ideais e ídolos; em índices, imagens e ícones; no comércio e na mercadoria; em continuidade e descontinuidade; em sinais, signos, significantes e símbolos; em gestos, posições, conteúdos; em frequências, entonações, ritmos, inflexões; em presenças e ausências; em palavras, em ações, em silêncios; em visões e silogismos. É a organização da própria variedade (WILDEN, 200I, p. II).

Do mesmo modo, energia é um conceito que nossos sentidos percebem por suas muitas formas: calor, luz, som, eletricidade, movimento, trabalho físico, porrada... É um conceito unificador que pode ser resumido na famosa fórmula de Einstein: o produto da massa pela velocidade ao quadrado. Informação é um conceito unificador, também, mas nem sempre matematicamente formalizável, porque trata de relações sistêmicas muito mais complexas, nas quais o aleatório, o eventual, o "ruído" precisam ser necessariamente considerados, daí abordados por métodos qualitativos.

O processo informacional, dialeticamente, insere-se num sistema lógico que articula suas mediações, desde as mais amplas, gerais, amorfas relações físico-químicas nas quais o sujeito está inserido (a variedade, no conceito de Wilden) até à produção e comunicação da forma concreta que orientará a ação comunicativa, conforme vemos na figura I: 
Figura 1 - As mediações da informação (Wilden, 2001)

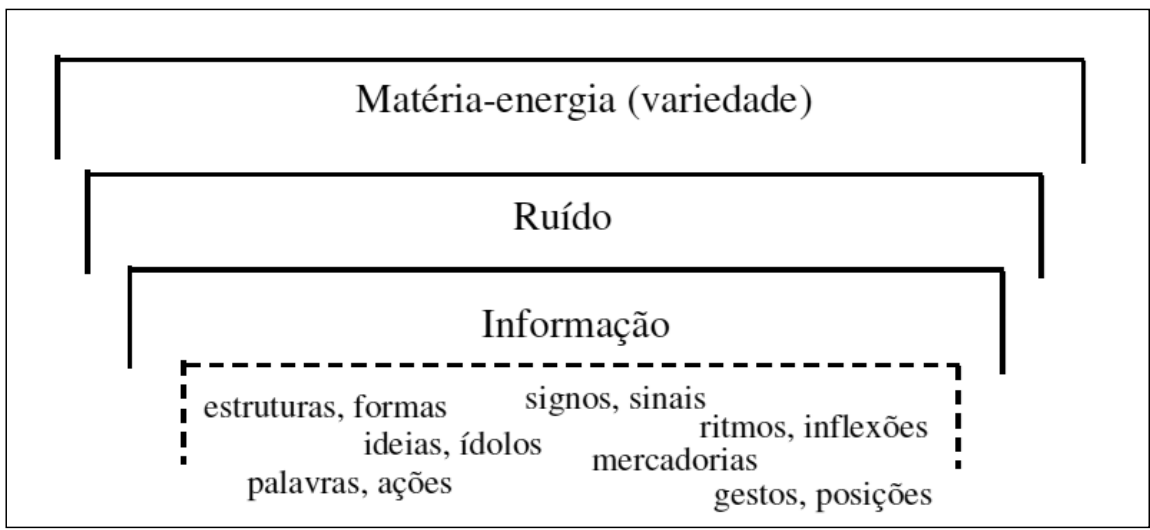

A “variedade" é o mundo que nos cerca, é tudo que está à nossa volta, nos limites máximos dos nossos sentidos e também dos nossos conhecimentos, para o qual não prestamos necessariamente atenção, mas nem por isso, dado um evento inesperado qualquer, podemos nos deixar ficar totalmente desatentos. O "ruído" seria um primeiro nível de diferenciação, quando recortamos no entorno as variações de matéria-energia que nos podem ser úteis em uma ação, determinados os seus objetivos, contextos, circunstâncias. É a seção do real à nossa volta, à qual atribuímos algum significado. Informação será a seleção definitiva, a relação sujeito-objeto identificada numa mesma ação, o trabalho orientado a um fim cuja significação está expressa na sua prática imediata, logo, na forma que assume em função dessa prática: pode ser "notícia", pode ser "arte", pode ser "mercadoria" etc. Ou seja, em se tratando de informação sociocultural humana, será o produto da linguagem que a informação-trabalho empregou na sua ação neguentrópica imediata.

\section{VALOR: INFORMACÃO SEMIÓTICA}

Tanto Wilden (200I) quanto Capurro e Hjørland (2007) nos ensinam que, até o início da modernidade, a palavra original em latim (informatio, -onis) significava "pôr em forma", "moldar", também "educar", e daí remetia a conceitos cosmológicos ("Deus informou o mundo"), conforme empregada por Santo Agostinho e São Tomás de Aquino. Esse conteúdo epistemológico teria sido esvaziado pelo grande movimento intelectual europeu, a partir dos séculos XVI-XVII, de rejeição à antiga ciência de fundo aristotélico-tomista, superada pela nova ciência que nascia com Bacon, Galileu, Newton, Leibniz etc. Então, informação é rebaixada a seu uso ordinário, substituída, no discurso científico e intelectual, por palavras tais como ideia, conhecimento, ciência etc.

Anthony Wilden acusa:

O nosso trissecular sistema socioeconômico, em conjunto com a epistemologia e a ideologia que o acompanham, manifesta ainda hoje uma particular obtusidade à aplicação e à compreensão das relações informacionais, uma 


\section{A troca de mercadorias, pois, é uma comunicação semiótica na qual a forma verbal da linguagem humana, natural na interação entre humanos, é transferida para uma forma icônica de linguagem "entre coisas" - o valor da mercadoria}

atitude refratária ao seu uso no interesse da sobrevivência a longo prazo [...]. A já tradicional incapacidade de reconhecer as relações informacionais parece ser uma característica peculiar da sociedade moderna, ao contrário do que acontece em todas as outras sociedades de que se tem conhecimento (WILDEN, 200I, p. 6I).

Um amplo conjunto de processos científicos ou, mais gerais, na sociedade, desde as investigações cada vez mais profundas na matéria física, química e biológica até a crescente presença, na vida econômica e no nosso cotidiano, das tecnologias de informação e comunicação (desde o telefone, o rádio ou o cinema até a atual internet), vão suscitar o desenvolvimento de uma teoria específica, como vimos, pela qual a informação ganha novamente status epistemológico e teórico. Daí, passamos a contar com um conceito científico rigoroso de informação.

Talvez devido àquela cultura intelectual própria do século XIX, a palavra informação quase não aparece nos textos de Marx e Engels - às vezes, aqui e ali, surge como sinônimo de "notícia", "cartas", ou seja, conceito de senso comum. No entanto, ela se encontra nos textos dos fundadores da economia neoclássica: William Jevons (I835I882), Alfred Marshall (I842-I924), Léon Walras (I834-I9IO). Para eles, o funcionamento "ótimo" ou "em equilíbrio" do mercado dependia de a "informação" estar equitativamente disponível e acessível. Referem-se à informação na forma de preços, qualidade da mercadoria, condições de entrega etc. ("dados organizados e comunicados", como definiria, vimos, Marc Porat). Descrevem o mercado como uma espécie de feira livre na qual vendedores e compradores encontram-se numa situação de amplo e livre acesso às "informações" necessárias à compra e venda dos produtos expostos nas barracas. Nas suas equações matemáticas, essa forma de informação aparece como constante neutra.

Marx também aborda a informação, embora omita a palavra. Conforme escreveu em $O$ Capital, a mercadoria "revela seu pensamento em sua linguagem exclusiva, a linguagem das mercadorias" (MARX, 1983, p. 57). A mercadoria, diz-nos ainda, nos Grundrisse, é "simples signo, uma letra para uma relação de produção, um simples 
signo de seu próprio valor" (MARX, 20II, p. 9I, grifos nossos). A troca de mercadorias, pois, é uma comunicação semiótica na qual a forma verbal da linguagem humana, natural na interação entre humanos, é transferida para uma forma icônica de linguagem "entre coisas" - o valor da mercadoria. O conceito de valor é semiótico: não se encontra no objeto em si, mas no que ele significa no sistema de relações sociais determinado pelas leis de valorização do capital (DANTAS, 2018).

A semiótica é a forma geral da informação precipuamente humana. O signo, explicou Escarpit (I99I, p. 85), é "a percepção de uma variação de energia que denota outra coisa além da própria existência”. Para Vieira Pinto, na espécie humana, por força da sua evolução, "o sinal passa a ter uma ligação direta com a produção social, e na verdade recebe da sociedade onde se origina o significado que lhe é reconhecido, ou seja, o conteúdo da informação que comporta" (VIEIRA PINTO, 2005, p. 4I7). Ainda que nosso pensador muito raramente utilize a palavra signo, nessa e em muitas outras passagens, algumas já citadas anteriormente neste artigo, deixa claro que o significado, ou seja, o conteúdo do signo, é a forma necessariamente humana da informação.

Falar, por exemplo, é produzir vibrações nas frequências sonoras, mas de modo a pôr em forma (in-formar) essas vibrações em frequências específicas que nossa cultura aprendeu a identificar como fonemas formando palavras, formando frases, formando textos. A fala desaparece - é dissipada - assim que falada, não se conserva; mas o material semântico que transporta é transferido por ela de uma matéria cerebral a outra matéria cerebral, conservando-se em ambas, ainda que associadas a outras imagens mentais. Trata-se de trabalho informacional, mas, nesse nível humano, a informação ganha uma dimensão especial, pois, pelo signo, é teleologicamente carregada de sentidos, significados, significações: informação semiótica.

Todas as relações humanas são semioticamente mediadas, ou seja, atravessadas por algum sistema de signos. A comunicação só é possível se os polos em interação são capazes de operar algum sistema de signos comum: um falante de uma língua só é capaz de se comunicar com falante de outra língua se um dos dois domina o código sintático e semântico do outro ou se ambos dominam um terceiro código. Ao afirmar que a mercadoria só fala sua própria linguagem, Marx quer dizer que a sociedade transferiu para um novo sistema sintático-semântico, para um novo plano semiótico, as mediações comunicativas, logo sociais, das próprias relações humanas. Porém, ensina Rossi-Landi, "a palavra como unidade de significante e significado é um produto do trabalho linguístico, e seu uso é um ulterior trabalho linguístico" (ROSSI-LANDI, I985, p. 92).

Na definição positivista de Saussure (1969), o signo é a unidade significante (seu suporte material externo)-significado (seu conceito mental). Ele só considera a "estrutura", os códigos dados que todo usuário de um sistema significativo (a língua, por exemplo) precisa conhecer para se comunicar corretamente - sem "ruídos"... Distingue a langue (estrutura da língua) da parole (prática da língua) como objeto de interesse dos estudos linguísticos. Responde Rossi-Landi: 
Objetos produzidos em conformidade com os modelos são, em geral, usados apenas em sua (nova) imediatez, como materiais e instrumentos; como tais, eles pertencem a sistemas institucionalizados de acordo com regularidades sociais não necessariamente ligadas às regras que constituem as supramencionadas planificações, mas, ao contrário, bastante distanciadas delas. Seja no mundo das mercadorias, seja no mundo das palavras, são essas regularidades, e não as regras operacionais para a satisfação das necessidades, que regem a troca e a circulação e que determinam o valor de troca dos objetos produzidos. Quanto a seu valor de troca, mercadorias e palavras se apresentam desligadas das operações que as produzem.

O que têm em comum todas as palavras, expressões e mensagens, quando se prescinde de seu valor de uso, é justamente o fato de serem palavras, expressões e mensagens, isto é, meros resultados do trabalho humano (ROSSI-LANDI, I985, p. 89-90, grifos originais).

Do ponto de vista do capital, esses "meros resultados" lhe apresentarão um enorme problema se a "palavra" (adotemos o termo como metáfora) não pode ser conservada em algum suporte material que possa durar o tempo necessário até completa efetuação da troca, isto é, se a "palavra" for imediatamente dissipada no instante mesmo da troca. Alimentos, roupas, equipamentos, máquinas têm diferentes tempos de decaimento entrópico, mas todos se conservam por algum tempo, maior ou menor, desde o momento em que a produção é concluída até o momento em que seus suportes chegam às mãos de algum consumidor final. Além disso, uma vez consumidos, precisam ser repostos. Mas objetos cujos valores de uso expressam "sentimentos", "emoções", "desejos", "afetos", logo, só podem ser trocados em relações sociais intersubjetivas, não possuem aquelas qualidades: não podem ser trocados, mas, sim, comunicados, e não são realmente consumidos, mas replicados ou reproduzidos infinitas vezes, se assim desejarmos, independentemente do suporte que os transporta. Até hoje, podemos ler Aristóteles, não importa se em papiro, papel ou Kindle...

Esse problema passaria a perseguir o capital à medida que, cada vez mais, sobretudo após a Segunda Guerra Mundial, o conteúdo de valor das mercadorias deslocava-se do tempo de trabalho fabril e de seus produtos entrópicos para o tempo de trabalho de cientistas e artistas, e seus produtos neguentrópicos. O primeiro a acusá-lo pode ter sido Norbert Wiener, em seu clássico Cibernética e sociedade. Já antecipando que, no capitalismo, a informação viria a ser tratada como mercadoria, deixava claro: "informação e entropia não se conservam e são inadequadas, uma e outra, para se constituírem em mercadorias" (WIENER, I978, p. II5). Relacionando os conceitos de Shannon à lógica do equilíbrio das teorias econômicas neoclássicas, Kenneth Arrow, na década de 1960 , iria igualmente demonstrar que informação não detém as propriedades típicas de mercadoria, e, por isso, sua organização para fins econômicos deveria considerá-la um "bem público" (ARROW, I962). Nas últimas décadas, Joseph Stiglitz vem provocando um amplo debate, nos termos do mainstream econômico, apontando 


\section{No capitalismo atual, ou capital-informação,}

\section{as fases industriais de transformação material} são, em grande parte, cada vez mais, efetuadas por sistemas de maquinaria: quase não há mais trabalho vivo nessas fases. A produção de valor pelo trabalho veio sendo progressivamente transferida para os trabalhos de pesquisa e desenvolvimento científico-tecnológicos, de projeto, de desenho, também para as muitas e cada vez mais ubíquas atividades identificadas ao "espetáculo"

para a necessidade de as suas formulações considerarem que a "informação" possui características que não permitem ao "sistema de preços" funcionar adequadamente nos termos dos modelos estabelecidos (STIGLITZ, 2000). Por esses modelos, a "única informação que pode ser distribuída 'eficientemente' é a informação sem custos" (p. I.460). Naturalmente, tal solução desestimularia o investimento privado, daí que será necessário buscar mecanismos institucionais que possam tanto estimular o investimento quanto também assegurar os benefícios sociais esperados. Stiglitz segue os procurando...

A evolução recente da internet e amplo conjunto de outros eventos sociais e políticos, cujos fundamentos se encontram na "mercadificação" da informação, têm levado à produção de novas teorias — que Vieira Pinto, muito provavelmente, na sua linguagem própria, chamaria de "ingênuas" - buscando ajustar essas emergentes contradições sociais ao sistema político-econômico capitalista. Cresce uma literatura formalmente crítica em torno da atraente palavra-chave comum (LESSIG, 2005; HESS e OSTROM, 20II; DARDOT e LAVAL, 20I7). Mais uma vez, esses e outros autores e autoras estão discutindo alguma forma da informação sem descer à sua real substância: o trabalho.

No capitalismo atual, ou capital-informação (DANTAS, I996; I999; 20I7), as fases industriais de transformação material são, em grande parte, cada vez mais, efetuadas por sistemas de maquinaria: quase não há mais trabalho vivo nessas fases. A produção de valor pelo trabalho veio sendo progressivamente transferida para os trabalhos de pesquisa e desenvolvimento científico-tecnológicos, de projeto, de desenho, também para as muitas e cada vez mais ubíquas atividades identificadas ao "espetáculo" (DEBORD, I997; FONTENELLE, 2002; JAPPE, 2013; JAMESON, 2006; HARVEY, 1996). 
Como consequência, patentes, copyrights, "direitos de imagem" e outras formas de direitos de propriedade intelectual (DPIs) assumiram um papel determinante no processo de acumulação de capital (ORMAY, 20I8).

Para entender a lógica de acumulação do capital-informação, consideremos um professor, em sala de aula, assalariado de alguma instituição particular de ensino. $O$ valor de seu trabalho encontra-se na sua atividade em sala de aula, no conhecimento que transfere aos estudantes, através da sua voz, movimentos de corpo, circunstancialmente auxiliados por ferramentas como giz, quadro negro, ou televisão e computadores. O valor de seu trabalho encontra-se na parole, não na langue, na ação, não em algum objeto congelado qualquer que se possa conservar como mercadoria. Um capitalista investe dinheiro para adquirir as instalações da escola, seus recursos de apoio e, principalmente, seus professores e demais funcionários. O que atrairá "clientes" para essa escola será o trabalho concreto dos professores na interação informacional com seus estudantes. A utilidade da escola será medida principalmente pelos resultados desse trabalho na formação dos estudantes. $\mathrm{O}$ conhecimento detido na mente de professores e professoras é transferido, pelo trabalho-informação, para a mente dos estudantes sem que, porém, esse conhecimento deixe de permanecer também na mente dos professores.

O valor do trabalho do professor ou professora só pode ser mercadejado enquanto em ação: seu efeito útil coincide, no tempo e no espaço, com sua atividade de aula, com a interação que mantém com seus estudantes, seja em sala de aula, seja corrigindo provas e trabalhos, seja dialogando com seus orientandos e orientandas. Aqui não há, a rigor, produção de alguma nova mercadoria. Os estudantes (ou seus pais) consomem imediatamente e pagam diretamente o trabalho vivo dos professores $\mathrm{e}$ professoras. Essa atividade viva interativa de professores e estudantes produz mais-dinheiro (mais-valor) sem que seja produzido algum novo produto material para mediar a troca. A rigor, não há troca, há comunicação - pôr em comum. Processos similares, com as devidas adaptações, podemos observar nas indústrias de elevado conteúdo científico-tecnológico, nas indústrias baseadas em marcas (quase todas o são hoje em dia), nas indústrias culturais (por demais evidente), nos esportes profissionais etc.

O produto do trabalho, substanciado na mente dos estudantes posta em forma na escola, não é similar ao do trabalho fabril, de, por exemplo, pôr na forma de automóveis algumas toneladas de aço. Na fábrica, a forma resultante é morta; é reprodutível em centenas e centenas de exemplares iguais; e preserva-se por algum tempo, embora decaindo pouco a pouco enquanto material e enquanto valor, conforme as leis da termodinâmica. A mercadoria, no conceito clássico, de Marx, é um produto entrópico. Na escola, a forma resultante do trabalho do professor com seus alunos e alunas é também viva. O produto é neguentrópico. Na produção de automóveis ou quaisquer outras mercadorias, o resultado é uma forma equivalente a outra, intercambiável no mercado. Forma-mercadoria: objetos "produzidos em conformidade com modelos", como poderia dizer Rossi-Landi (I985, p. 89), visando à troca. Mas se 
observarmos bem, mesmo nesse mercado de automóveis, as empresas, através do marketing e publicidade, destacam insistentemente a "beleza", a "potência", os "afetos" que podem fornecer aos consumidores os produtos que lhes vendem. Chamam a atenção para a diferença. O desenho externo, a tecnologia dos motores e, mais recentemente, os sistemas de software para "ajudar" o motorista, esses são os aspectos que devem impulsionar a troca, não a mera utilidade de locomoção. Carro, sabemos, é status social, distinção, nos termos de Bourdieu (2006). Também nas indústrias fabris, o trabalho mobilizado e embutido nos suportes mercantis tende a ser cada vez mais artístico e científico. O automóvel mesmo, essa massa físico-química de aço, plástico, vidro, borracha, isso os robôs podem montar. Mas são necessários engenheiros e engenheiras para projetar os robôs.

No século XIX, atividades ditas "intelectuais" ou "artísticas" estavam geralmente fora do circuito econômico. Seus profissionais, na maior parte, sustentavam-se prestando serviços pessoais, ou apoiados financeiramente por mecenas (sobretudo os artistas) ou ocupando cargos no serviço público, quando não eram aristocratas vivendo de renda. Em quaisquer dessas situações, podia-se admitir que viviam parasitariamente de alguma cota de mais-valor para eles transferida do trabalho produtivo fabril. No século XXI, inverteu-se a relação. Enquanto, cada vez mais, o capital transfere para máquinas, robôs, plataformas e aplicativos de internet, inteligência artificial etc., uma ampla gama de atividades que antes requeriam trabalho humano, mesmo que de baixa qualidade informacional; no mesmo processo segue obrigado a recrutar, mobilizar, organizar, explorar trabalho informacional vivo de qualidade criativa, sem o qual não pode desenvolver suas máquinas, plataformas, inteligências artificiais. $\mathrm{O}$ trabalho fabril, desde os tempos do taylor-fordismo, veio sendo reduzido a operações binárias, mensuráveis, nas quais os "ruídos" deviam ser controlados ao máximo, o erro devia ser reprimido. Por isso mesmo, pode ser substituído pela automação. Mas o trabalho criativo, ao contrário, trata exatamente do "ruído": o erro é pressuposto, é parte da experimentação, é função do processo de aprimoramento e expansão da organização. Para realizar o mais-valor extraído desse trabalho cujos tempos são de difícil mensuração, o capital precisa recorrer aos direitos de propriedade intelectual.

As patentes, o copyright, os "direitos de imagem" são registros semióticos do direito que um capitalista privado se atribui sobre algum resultado do trabalho vivo expropriado de cientistas, professores, artistas etc. Através desses instrumentos institucionais, ele impõe condições de acesso a quem deseja usufruir do valor de uso dos resultados desses trabalhos. A principal condição, claro, é preço, um preço que já não pode mais ser medido por algum valor de troca, pois o valor da informação será sempre função do tempo de trabalho vivo, mas do tempo despendido na própria atividade de criar, isto é, de remover incertezas, encontrar soluções, solucionar problemas, não no de reproduzir ou replicar o produto já criado (DANTAS, 20I4; 20I7). Nesse movimento, o próprio tempo é um fator de incerteza. Se é da natureza da informação (trabalho) manter os sistemas distantes do equilíbrio, produzir diferença pela diferença, 


\section{Uma correta compreensão dialético-materialista da informação, no caminho escavado por Álvaro Vieira Pinto, nos abre amplo campo de investigação para compreendermos muitos processos na sociedade atual}

nenhum modelo (teórico) de equilíbrio se sustenta, salvo, como pretendiam Jevons e demais fundadores desses modelos, numa relação em que possa haver seis indivíduos apostando, cada um, em cada uma das seis faces de um dado: incerteza nula, informação = o bit. Ninguém ganharia além do valor da própria aposta...

É o que Stiglitz descobre, mas não consegue entender, no seu formalismo lógico não dialético: o "mercado de informação" é "não convexo", daí, rebelde aos "convexos" modelos neoclássicos? . Uma vez produzido o que a linguagem neoclássica entende por uma "peça de informação", seus custos de produção poderão ser igualmente rateados, a um mesmo preço, pelo universo consumidor, mas desde que o capitalista detenha o direito monopolista de controlar o acesso, numa relação social similar àquela, no passado, de controle do acesso à terra. Os custos de produção de uma novela de TV, por exemplo, são rateados em cotas iguais por toda a sua audiência, que, sem sentir ou perceber, remunera esses custos através dos custos de marketing embutidos nos preços dos produtos que compra, estimulada pelos anúncios vistos nessa mesma TV. Além dos direitos de propriedade intelectual, a empresa de televisão ainda controla os canais físicos de acesso, sejam as frequências hertzianas atmosféricas, sejam cabeadas ou satelitais. O mais-valor extraído do trabalho vivo informacional (artistas, roteiristas etc.) assim "cercado" pelo capital assume a forma de renda: renda informacional (DANTAS, I999; 20I2; ZELLER, 2008; RIGI, 20I4; PAULANI, 20I6; ORMAY, 20I8).

\footnotetext{
Nos modelos neoclássicos de equilíbrio, os agentes podem efetuar um conjunto de escolhas não necessariamente excludentes que constituirão os pontos de uma mesma curva (de preços, de custos etc.) em forma convexa: num supermercado, um consumidor adquire uma cesta de produtos a diferentes preços que, no conjunto, atenderão à sua demanda ou necessidades. Num mercado de automóveis usados, no entanto, o comprador tende a não estar suficientemente informado sobre a "qualidade do veículo"; o vendedor pode querer enganá-lo. Essa "assimetria da informação" leva os agentes a investimentos divergentes na "aquisição de informação", isto é, os "custos" tendem a não convergir dependendo do lado em que se encontrem no mercado. A informação sobre a "qualidade do veículo" terá um "valor", mas o comprador possivelmente investirá, na obtenção dessa informação, tempo ou mesmo dinheiro (pode contratar um mecânico de confiança, por exemplo) não equivalentes aos investidos pelo vendedor. Para Stiglitz (2000, p. 1.457), nesses mercados "não convexos", "a possível não existência de equilíbrio de mercado pode talvez não ser tão surpreendente". O conceito de não convexidade é em geral aplicado aos estudos das "falhas de mercado", por exemplo, em monopólios, oligopólios e na "economia da informação".
} 


\section{CONCLUINDO}

Qualquer projeto de superação das relações capitalistas de produção, hoje em dia, deveria ter por foco central o enfrentamento do princípio, já um tanto "naturalizado" na sociedade, da propriedade intelectual e de outros modelos de "cercamento" do trabalho. Por isso, é tão necessário ao pensamento que se queira crítico e transformador compreender dialeticamente a informação na sua relação simbiótica com trabalho. Não há trabalho sem informação, nem informação sem trabalho.

Os conceitos correntes, formais, fenomênicos, segmentados, objetivados, tão somente servem para legitimar a apropriação direta da criatividade do trabalho pelo capital, ao reduzir a informação a "coisa" ou, numa outra ponta, a alguma subjetividade "imaterial" idealista. Uma correta compreensão dialético-materialista da informação, no caminho escavado por Álvaro Vieira Pinto, nos abre amplo campo de investigação para compreendermos muitos processos na sociedade atual, desde a dimensão cultural e econômica do futebol, com seus craques hiperbem pagos se exibindo pela televisão, até a mobilização, por aplicativos de celulares, de milhares de indivíduos superexplorados nas atividades informacionais de carregar, sobre bicicletas ou motocicletas, encomendas de alimentos e outros produtos para pessoas isoladas em suas residências durante estes tempos de pandemia de covid-I9. O valor está no trabalho vivo posto literalmente em movimento, em ação, seja atrás de uma bola, seja sobre o selim de uma moto. No entanto, segue apropriado e privatizado, agora por meio das marcas ("a mercadoria é simples signo") que esse trabalho exibe, seja nas camisetas que o jogador veste num campo de futebol ou nas sacolas de iFood ou UberEats penduradas nas costas do motoboy. Como mobilizar, conscientizar, organizar esses tão diferenciados segmentos de trabalhadores nesta época do capital-informação, bem... isso é um outro problema, muito além dos objetivos e dimensões deste artigo.

\footnotetext{
* Professor titular da Escola de Comunicação da Universidade Federal do Rio de Janeiro (ECO-UFRJ), dos programas de pós-graduação em Comunicação e Cultura da ECO e de Ciência da Informação do Instituto Brasileiro de Informação em Ciência e Tecnologia (UFRJ). É doutor em Engenharia de Produção pelo Instituto Alberto Luiz Coimbra de Pós-Graduação e Pesquisa de Engenharia (UFRJ) e mestre em Ciência da Informação pela ECO-UFRJ. É membro do Comitê Gestor da Internet do Brasil (CGl.br) e da Diretoria Executiva do Centro Internacional Celso Furtado de Políticas para o Desenvolvimento. Lidera o Grupo Marxiano de Pesquisa em Informação, Comunicação e Cultura (ComMarx), que, entre outras atividades, tem-se dedicado ao estudo da obra e pensamento de Álvaro Vieira Pinto. URL: www.marcosdantas.br
}

Texto recebido em 6 de junho de 2021; aprovado em 7 de junho de 2021. 
ARROW, Kenneth J. Economic welfare and the allocation of resources for invention. In: NATIONAL BUREAU COMMITTEE FOR ECONOMIC RESEARCH. The rate and direction of inventive activity: economic and social factors. Princeton: Princeton University Press, 1962. p. 609-626.

ASHBY, W. Ross. Introdução à cibernética. São Paulo: Perspectiva, 1970.

ATLAN, Henri. Entre o cristal e a fumaça. Rio de Janeiro: Jorge Zahar, 1992.

Ruído e determinismo: diálogos espinosistas entre antropologia e biologia. Mana, v. 9, n. 1, p. 123-137, abr. 2003.

BATESON, Gregory. Pasos hacia una ecología de la mente. Buenos Aires: Lohlé-Lumen, 1998.

BELL, Daniel. The coming of the post-industrial society. New York: Basic Books, 1973.

BENSAÏD, Daniel. Marx intempestivo: grandezas y miserias de una aventura crítica. Buenos Aires: Herramienta, 2003.

BOURDIEU, Pierre. A distinção: crítica social do julgamento. Porto Alegre: Zouk, 2006.

BRETON, Philippe. História da informática. São Paulo: Unesp, 1991.

BRILLOUIN, Léon. La science et la théorie de l'information. Paris: Jacques Gabay, 1988.

CAPURRO, Rafael; HJØRLAND, Birger. O conceito de informação. Perspectivas em Ciência da Informação, v. 12, n. 1, p. 148-207, jan.- abr. 2007.

CASTELLS, Manuel. A sociedade em rede. São Paulo: Paz e Terra, 1999. v. 1.

COPI, Irving M. Introdução à lógica. São Paulo: Mestre Jou, 1981.

DANTAS, Marcos. A lógica do capital-informação. Rio de Janeiro: Contraponto, 1996.

As rendas informacionais e a apropriação capitalista do trabalho científico e artístico. In: MARQUES, Rodrigo Moreno; RASLAN, Filipe; MELO, Flávia; PINHEIRO, Maria Macedo Kerr (Org.). A informação e o conhecimento sob as lentes do marxismo. Rio de Janeiro: Garamond, 2014. p. 35-60.

Capitalismo na era das redes: trabalho, informação, valor no ciclo da comunicação produtiva. In: LASTRES, Helena; ALBAGLI, Sarita (Org.). Informação e globalização na era do conhecimento. Rio de Janeiro: Campus, 1999. p. 216-161.

Information as work and as value. Triple C, n. 15, v. 2, p. 816-847, 2017. Disponível em: <www. triple-c.at/index.php/tripleC/article/view/885>. Acesso em: 22 jun. 2021.

Semiótica da mercadoria: para uma introdução à economia política do signo. Revista Eptic, v. 20, n. 1, p. 139-160, 2018. Disponível em: <https://seer.ufs.br/index.php/eptic/article/view/8519>. Acesso em: 22 jun. 2021

Trabalho com informação: valor, acumulação, apropriação nas redes do capital. Rio de Janeiro: CFCH/ECO-UFRJ, 2012. Disponível em: <http://marcosdantas.com.br/conteudos/wpcontent/uploads/2013/03/livro_trabalho_com_informacao_marcos_dantas.pdf $>$. Acesso em: 8 jun. 2021.

DARDOT, Pierre; LAVAL, Christian. Comum: ensaio sobre a revolução no século XXI. São Paulo: Boitempo, 2017.

DEBORD, Guy. A sociedade do espetáculo. Rio de Janeiro: Contraponto, 1997.

DUPUY, Jean-Pierre. Nas origens das ciências cognitivas. São Paulo: Editora Unesp, 1995.

ENGELS, Friedrich. Dialética da natureza. São Paulo: Boitempo, 2020.

ESCARPIT, Robert. L'information et la communication. Paris: Hachette Livre, 1991. 
FOERSTER, Heinz von. Epistemology of communication. In: WOODWARD, Kathleen (Ed.). The myths of information: technology and post-industrial culture. London: Routledge \& Kegan Paul, 1980.

On self-organizing systems and their environments. In: YOVITS, Marshall C.; CAMERON, Scott (Ed.). Self-organizing systems. Oxford: Pergamon, p. 31-50, 1960.

FONTENELLE, Isleide. O nome da marca: McDonald's, fetichismo e cultura descartável. São Paulo: Boitempo, 2002

FOSTER, John Bellamy; BURKETT, Paul. Classical marxism and the second law of thermodynamics: Marx/Engels, the heat death of the universe hypothesis, and the origins of ecological economics. Organization \& Environment, v. 21, n. 1, p. 3-37, jan. 2008. Disponível em: <https://johnbellamyfoster. org/wp-content/uploads/2014/07/Organization-Environment-2008-Bellamy-Foster-3-371.pdf>. Acesso em: 4 jun. 2021.

FREITAS, Marcos Cezar de. O conceito de tecnologia: o quarto quadrante do círculo de Álvaro Vieira Pinto. In: VIEIRA PINTO, Álvaro. O conceito de tecnologia. Rio de Janeiro: Contraponto, 2005.

GOLDMANN, Lucien. Importancia del concepto de conciencia posible para la comunicación. In: GUÉROULT, Marcial (Ed.). El concepto de información em la ciencia contemporânea: Colóquios de Royumont. México: Siglo XXI, 1970. p. 31-54.

GONZATTO, Rodrigo Freese; MERKLE, Luiz Ernesto. Vida e obra de Álvaro Vieira Pinto: um levantamento biobibliográfico. Revista HISTEDBR On-line, n. 69, p. 286-310, set. 2016. Disponível em: <https://periodicos.sbu.unicamp.br/ojs/index.php/histedbr/article/view/8644246>. Acesso em 22 jun. 2021>.

GUILLAUMAUD, Jacques. Cibernética e materialismo dialético. Rio de Janeiro: Tempo Brasileiro, 1970.

HARVEY, David. Condição pós-moderna. São Paulo: Loyola, 1996.

HESS, Charlotte; OSTROM, Elinor (Ed.). Understanding knowledge as a commons. Cambridge: The MIT Press, 2011

JAMESON, Fredric. Pós-modernismo: a lógica cultural do capitalismo tardio. São Paulo: Ática, 2006. JAPPE, Anselm. As aventuras da mercadoria: para uma nova crítica do valor. 2. ed. Lisboa: Antígona, 2013.

LEFEBVRE, Henri. Le retour de la dialectique. Paris: Messidor, 1986.

LESSIG, Lawrence. Cultura livre: como a grande mídia usa a tecnologia e a lei para barrar a criação cultural e controlar a criatividade. São Paulo: Trama, 2005.

MACHLUP, Fritz. The production and distribution of knowledge in the United States. Princeton: Princeton University, 1962.

MATTELART, Armand. História da sociedade da informação. São Paulo: Loyola, 2001.

MARX, Karl. O Capital: crítica da economia política. Livro 1. São Paulo: Abril Cultural, 1983.

Grundrisse: manuscritos econômicos de 1857-1858. São Paulo: Boitempo, 2011.

; ENGELS, Friedrich. A ideologia alemã. São Paulo: Boitempo, 2007.

MOLES, Abraham. Teoria da informação e percepção estética. 2. ed. Rio de Janeiro: Tempo Brasileiro, 1978.

ORMAY, Larissa. Propriedade intelectual e renda no capital-informação. 2018. Tese (Doutorado em Ciência da Informação) — ECO-Ibict, Universidade Federal do Rio de Janeiro, Rio de Janeiro, 2018.

PAULANI, Leda Maria. Acumulação e rentismo: resgatando a teoria da renda de Marx para pensar o capitalismo contemporâneo. Revista de Economia Política, v. 36, n. 3, p. 514-535, 2016. 
PETERS, Benjamin. Normalizing Soviet cybernetics. Information \& Culture, v. 47, n. 2, p. 145-175, 2012. Disponível em: <http://nevzlin.huji.ac.il/userfiles/files/47.2.peters.pdf>. Acesso em: 8 jun. 2021. PRIGOGINE, Ilya; STENGERS, Isabelle. A nova aliança. Brasília: Editora UnB, 1997.

Entre o tempo e a eternidade. São Paulo: Companhia das Letras, 1992.

RAPOPORT, Anatol. Aspectos matemáticos da análise geral dos sistemas. In: ANOHIN, Pyotr K. et al. Teoria dos sistemas. Rio de Janeiro: Editora FGV, 1976.

RICHTA, Radovan. La civilización en la encrucijada. México; Madrid; Buenos Aires: Siglo XXI, 1971.

RIGI, Jakob. Foundations of a Marxist theory of the political economy of information: trade secrets and intellectual property, and the production of relative surplus value and the extraction of rent-tribute. Triple C, v. 12, n. 2, p. 909-936, 2014.

ROSSI-LANDI, Ferruccio. A linguagem como trabalho e como mercado. São Paulo: Difel, 1985.

SAUSSURE, Ferdinand. Curso de linguística geral, São Paulo: Cultrix; Edusp, 1969.

SCHRÖDINGER, Erwin. $\mathbf{O}$ que é vida?: o aspecto físico da célula viva, seguido de Mente e matéria e Fragmentos autobiográficos. São Paulo: Editora Unesp, 1997.

SFEZ, Lucien. Crítica da comunicação, São Paulo: Loyola, 1994.

SHANNON, Claude. A mathematical theory of communication. The Bell System Technical Journal, v. 27, p. 379-423, 623-656, jul.-out. 1948.

; WEAVER, Warren. Teoria matemática da comunicação, Rio de Janeiro: Difel, 1975.

STIGLITZ, Joseph E. The contributions of the economics of information to twentieth century economics. The Quarterly Journal of Economics, v. 115, n. 4, p. 1.441-1.478, 2000.

VIEIRA PINTO, Álvaro. Ciência e existência. Rio de Janeiro: Paz \& Terra, 1979.

O conceito de tecnologia. Rio de Janeiro: Contraponto, 2005. v. 2.

WIENER, Norbert. Cibernética e sociedade: o uso humano de seres humanos. São Paulo: Cultrix, 1978.

Cybernetics: or Control and communication in the animal and the machine. Cambridge: The MIT Press, 1985.

WILDEN, Anthony. Informação. In: Enciclopédia Einaudi: comunicação-cognição. Lisboa: Imprensa Nacional; Casa da Moeda, 2001. v. 34.

System and structure. 2. ed. London; New York: Tavistock, 1980.

ZELLER, Christian. From the gene to the globe: extracting rents based on intellectual property monopolies. Review of International Political Economy, v. 15, n.1, p. 86-115, 2008. 